Article

\title{
Viburnum opulus L. Juice Phenolics Inhibit Mouse 3T3-L1 Cells Adipogenesis and Pancreatic Lipase Activity
}

\author{
Małgorzata Zakłos-Szyda *(D), Nina Pietrzyk (D), Marcin Szustak and Anna Podsędek (D) \\ Department of Biotechnology and Food Sciences, Institute of Molecular and Industrial Biotechnology, \\ Lodz University of Technology, 90-924 Łódź, Poland; nina.pietrzyk@dokt.p.lodz.pl (N.P.); \\ marcin.szustak@p.lodz.pl (M.S.); anna.podsedek@p.lodz.pl (A.P.) \\ * Correspondence: malgorzata.zaklos-szyda@p.lodz.pl
}

Received: 4 June 2020; Accepted: 23 June 2020; Published: 6 July 2020

check for updates

\begin{abstract}
Viburnum opulus L. fruit is a rich source of phenolic compounds that may be involved in the prevention of metabolic diseases. The purpose of this study was to determine the effects of Viburnum opulus fresh juice (FJ) and juice purified by solid-phase extraction (PJ) on the adipogenesis process with murine 3T3-L1 preadipocyte cell line and pancreatic lipase activity in triolein emulsion, as well as their phenolic profiles by UPLC/Q-TOF-MS. Decrease of lipids and triacylglycerol accumulation in differentiated 3T3-L1 cells were in concordance with downregulation of the expression of peroxisome proliferator-activated receptor-gamma (PPAR $\gamma), \mathrm{CCAAT} /$ enhancer-binding protein alpha $(\mathrm{C} / \mathrm{EBP} \beta / \alpha)$, and sterol regulatory element-binding protein 1c (SREBP-1c). Furthermore, regulation of PPAR $\gamma$-mediated $\beta$-lactamase expression by $V$. opulus components in reporter gene assay, as well as their binding affinity to ligand-binding domain of PPAR $\gamma$, were tested. In addition, the levels of enzymes involved in lipid metabolism, like fatty acid synthase (FAS) or acetyl-CoA carboxylase (ACC), were decreased, along with inflammatory cytokines, like tumor necrosis factor $\alpha$ (TNF $\alpha$ ), interleukin-6 (Il-6) and leptin. Moreover, FJ and PJ were able to inhibit pancreatic lipase, which potentially could reduce the fat absorption from the intestinal lumen and the storage of body fat in the adipose tissues. Thirty-two phenolic compounds with chlorogenic acid as the dominant compound were identified in PJ which revealed significant biological activity. These data contribute to elucidate $V$. opulus juice phenolic compounds' molecular mechanism in adipogenesis regulation in 3T3-L1 cells and dietary fat lipolysis.
\end{abstract}

Keywords: Viburnum opulus; phenolic compounds; adipogenesis; PPAR $\gamma$; lipase inhibition

\section{Introduction}

Nutrition-related chronic diseases have become the main health problem of the world of the 21st century. According to World Health Organization data based on the latest, in the European Union countries overweight and obesity affect $30-70 \%$ and $10-30 \%$ of adults, respectively [1]. Obesity is characterized as abnormal or excessive fat accumulation, which means the increase in the number (hyperplasia) and size (hypertrophy) of differentiated adipocytes [2,3]. It is known that adipose tissue is not only a reservoir of energy in the form of triacyclglycerols (TAG), but it also secretes adipocytokines, growth factors, and hormones involved in energy homeostasis and insulin sensitivity maintenance. Thus, increased adiposity is regarded as one of the most important risk factors of insulin resistance, type 2 diabetes (T2D), and nonalcoholic fatty liver disease (NAFLD), which in turn may lead to hypertension, coronary heart disease, and stroke [4]. Among the most important cellular regulators of lipid metabolism are peroxisome proliferator-activated receptors (PPARs), belonging 
to nuclear receptors proteins [5]. There are three different receptor isotypes: PPAR $\alpha, \operatorname{PPAR} \beta / \delta$, and PPAR $\gamma$, among which PPAR $\gamma$ is involved in the regulation of adipocyte differentiation. Ligand binding to the PPAR $\gamma$ ligand-binding domain (LBD) leads to a conformational change and switching of nuclear receptor corepressors to coactivators [6]. Agonists activate PPAR $\gamma$, which, after binding with retinoic $X$ receptor and peroxisome proliferator responsive element (PPRE) within the promoter of target genes activates their transcription [7]. Not only PPAR $\gamma$ but also other transcription factors, such as CCAAT/enhancer-binding protein alpha $(\mathrm{C} / \mathrm{EBP} \beta / \alpha)$ and sterol regulatory element binding protein-1c (SREBP-1c), are involved in adipocyte differentiation [8]. These factors stimulate gene expression and the expression of other proteins involved in lipid synthesis and storage, such as fatty acid synthase (FAS) or acetyl-CoA carboxylase (ACC). What is more, obese adipose tissue contributes to the elevation of inflammatory cytokines, such as tumor necrosis factor $\alpha$ (TNF $\alpha)$ or interleukin-6 (Il-6), leading to chronic inflammation state promoting insulin resistance and cancer development [9]. PPAR $\gamma$ agonist type of medicines, like glitazones, significantly improve glycemic control, but via promotion of free fatty acid uptake and accumulation of TAG in adipose tissue lead to weight gain, and increases in heart or renal failure [10-12]. Thus, due to the variety of induced side effects, less harmful plant-derived agents are searched as PPAR $\gamma$ regulators able to prevent insulin resistance without weight obesity gaining. Other mechanisms allowing the decrease of fatty acids intestinal absorption is the usage of pancreatic lipase inhibitor, which decreases the hydrolysis of diet-originated TAG into glycerol and fatty acids. Since phenolic compounds constitute an important part in the human diet, they have recently emerged as critical phytochemicals in obesity prevention and treatment $[13,14]$. Among fruits rich in these secondary metabolites are those of Viburnum opulus L. (V. opulus L.), known as guelder rose, or the European cranberry bush rose $[15,16]$. Despite its fruit bitterness it can be found in food products such as juice, jams, jellies, marmalades, sauces, herbal tea, cordials, and liqueurs, as well as fermented drinks [17]. Our previous studies showed that due to their high antioxidant potential $V$. opulus phenolics decreased chemically generated intracellular oxidative stress under in vitro conditions, as well as possessed different anticancer activity with apoptosis induction and inhibition of cell migration $[16,18,19]$. Further studies revealed $V$. opulus fruit phenolics' impact on carbohydrate metabolism as $\alpha$-amylase, $\alpha$-glucosidase, protein tyrosine phosphatase- $1 \mathrm{~B}$, and dipeptidyl peptidase- 4 enzyme inhibitors $[20,21]$. More detailed analysis showed that $V$. opulus phenolics decreased the uptake of free fatty acids and lipids accumulation in human epithelial Caco-2 cells [15]. Nevertheless, they inhibited glucose-stimulated insulin secretion in mice insulinoma MIN6 cells, as well as increased free fatty acid uptake and lipid droplets accumulation [21]. Taking into account potent phenolics' impact on the modulation of cellular metabolism, in the present study we investigated an influence of $V$. opulus fresh juice (FJ) and purified juice (PJ) on pancreatic lipase activity and adipogenesis process in mouse preadipocyte 3T3-L1 cell line [22]. In addition, phenolic components of FJ and PJ were identified by the UPLC-MS method. Studies also assessed the influence of these preparations on the expression of transcription factors (PPAR $\gamma, \mathrm{C} / \mathrm{EBP}, \mathrm{SREBP} 1 \mathrm{c})$ and other proteins related to adipogenesis (FAS, ACC, $\mathrm{TNF} \alpha$, Il-6, leptin, adiponectin). Furthermore, the $V$. opulus components' influence on the regulation of $\operatorname{PPAR} \gamma$ activity was elucidated.

\section{Materials and Methods}

\subsection{Chemicals and Reagents}

Acetonitrile (Merck, Darmstadt, Germany) and formic acid (Sigma-Aldrich, Steinheim, Germany) were hyper grades for LC-MS. Folin-Ciocalteu reagent was obtained from POCH (Gliwice, Poland). The reference compounds were obtained from Sigma-Aldrich (Steinheim, Germany) $((+)$-catechin, (-)-epicatechin, rutin, gallic acid), Extrasynthese (Lyon, France) (chlorogenic acid, cyanidin 3-glucoside, quercetin 3-glucoside, isorhamnetin, and isorhamnetin 3-rutinoside) and Phytolab (Vestenbergsgreuth, Germany) (neochlorogenic acid, procyanidin B1, and procyanidin B2). Ultrapure water (Simplicity@Water Purification System, Millipore, Marlborough, MA, USA) was used to prepare 
all the solutions. All cell culture reagents were obtained from Life Technologies (Carlsbad, CA, USA). Other chemicals used, if not stated otherwise, were obtained from Sigma-Aldrich (Steinheim, Germany).

\subsection{Preparation of V. opulus Samples, Identification and Quantitative Determination of Individual Phenolic Compounds by UPLC-PDA-Q/TOF-MS}

Fruits of the V. opulus were collected from Rogów Arboretum, Warsaw University of Life Sciences (Rogów, Poland) (account number 18162). After fruit pulp homogenization and centrifugation (5000 rpm for $10 \mathrm{~min}$ ), fresh juice (FJ) was obtained. FJ purification by solid phase extraction with C-18 Sep-Pak cartridge (10 g capacity, Waters Corp., Milford, MA, USA; 12-Port Vacuum Manifold system) and methanolic elution processes were performed. After methanol removal under reduced pressure $\left(\mathrm{T}<40^{\circ} \mathrm{C}\right.$ ), solid residue was dissolved in water and lyophilized to purified juice (PJ). Phenolic compounds were identified using the Acquity ultraperformance liquid chromatography (UPLC) system coupled with a quadruple-time of flight mass spectrometry (Q/TOF-MS) instrument (Waters Corp., Milford, MA, USA) equipped with an electrospray ionization (ESI) source. The separation of individual phenolics was carried out using an Acquity UPLCR HSS T3 C18 column $(150 \times 2.1 \mathrm{~mm}, 1.8 \mu \mathrm{m}$; Corp., Milford, MA, USA) at $30{ }^{\circ} \mathrm{C}$. The mobile phase was a mixture of $0.1 \%$ formic acid (A) and acetonitrile (B). The gradient program was as follows: initial conditions 99\% (A), $12 \mathrm{~min} 65 \%$ (A), $12.5 \mathrm{~min} 100 \%$ (B), $13.5 \mathrm{~min} 99 \%$ (A). The flow rate was $0.45 \mathrm{~mL} / \mathrm{min}$ and the injection volume was $5 \mu \mathrm{l}$. The mass spectrometer was operating in the negative mode for a mass range of 150-1500 Da, fixed source temperature at $100{ }^{\circ} \mathrm{C}$, desolvation temperature $250{ }^{\circ} \mathrm{C}$, desolvation gas flow of $600 \mathrm{~L} / \mathrm{h}$, cone voltage of $45 \mathrm{~V}$, a capillary voltage of $2.0 \mathrm{kV}$, and a collision energy of $50 \mathrm{~V}$. Leucine enkephalin was used as a lock mass. The instrument was controlled by Mass-LynxTM V 4.1 software (Waters Corp., Milford, MA, USA). The runs were monitored at the following wavelengths: flavanols at $280 \mathrm{~nm}$, hydroxycinnamic acids at $320 \mathrm{~nm}$, flavonols at $360 \mathrm{~nm}$, and anthocyanins at $520 \mathrm{~nm}$. Photodiode detector (PDA) spectra were measured over the wavelength range of 200-600 nm. Calibration curves were run for the external standards: (+)-catechin, procyanidin C1, neochlorogenic acid, chlorogenic acid, cryptochlorogenic acid, caffeic acid, and quercetin 3-rutinoside, and quercetin 3-glucoside. Phenolic compounds were identified using their UV-Vis characteristic, MS and MS2 properties using data gathered in-house and from the literature.

\subsection{Inhibition Assay for Pancreatic Lipase Activity}

Inhibitory activities of $\mathrm{FJ}$ and $\mathrm{PJ}$ were expressed as the $\mathrm{IC}_{50}$ values (half-maximal inhibitory concentration). Orlistat was used as a positive inhibitor control. The $\mathrm{IC}_{50}$ value was concluded from the graph of lipase inhibition (\%) versus the concentration of juices or Orlistat per $1 \mathrm{~mL}$ of the reaction mixture under assay conditions. The pancreatic lipase activity was tested by measuring the fatty acids released from emulsified triolein $(0.6 \mathrm{~g}$ of triolein, $25 \mathrm{~mL}$ of Tris-buffer, and $0.4 \mathrm{~g}$ of bile acids) according to the method described previously [23]. Briefly, $0.3 \mathrm{~mL}$ of FJ, PJ, and orlistat solutions diluted with buffer were mixed with $0.5 \mathrm{~mL}$ of the triolein emulsion and pre-incubated at $37^{\circ} \mathrm{C}$ for 5 min before adding lipase supernatant $(0.063 \mathrm{~mL})$. Blanks with buffer instead of the lipase supernatant were prepared for background correction. The control consisted of all solutions without inhibitor. Finally, the reaction mixtures were incubated in a shaking bath $(200 \mathrm{rpm})$ at $37^{\circ} \mathrm{C}$ for $30 \mathrm{~min}$. The reaction was terminated by adding $0.23 \mathrm{~mL}$ of $\mathrm{HCl}$. Then, $3 \mathrm{~mL}$ of isooctane was added and vortexed for $0.5 \mathrm{~min}$. The upper layer $(2 \mathrm{~mL})$ was collected, followed by the addition of $0.4 \mathrm{~mL}$ copper reagent $(5 \%$ copper acetate, $\mathrm{pH} 6.1$ regulated by pyridine). After vortexing for $1 \mathrm{~min}$, the upper layer was centrifuged at 10,000 rpm for $10 \mathrm{~min}$ and its absorbance (A) was measured at $720 \mathrm{~nm}$ against a reagent blank. All samples were assayed in triplicate. Percent inhibition of pancreatic lipase activity was calculated using the formula:

$$
\text { Lipase inhibition }(\%)=\left[\left(A_{c}-A_{c b}\right)-\left(A_{s}-A_{s b}\right)\right] /\left(A_{c}-A_{c b}\right) \times 100
$$


where $A_{c}$ is the absorbance of the control, $A_{c b}$ is the blank control absorbance, $A_{s}$ is the sample absorbance, $\mathrm{A}_{\mathrm{sb}}$ is the sample blank.

\subsection{Cell Culture and Exposure Conditions}

Mouse preadipocytes 3T3-L1 were supplied by ATCC (Manassas, VA, USA). Preadipocytes were grown in Dulbecco's Modified Eagle's Medium (DMEM) medium with high glucose supplemented with $10 \%$ bovine calf serum. For adipocyte differentiation a confluent culture of 3T3-L1 cells was grown for two days in a preadipocyte medium DMEM with 10\% calf serum, then the cells were stimulated with a differentiation medium with DMEM containing $10 \%$ fetal bovine serum (FBS), $1 \mu \mathrm{M}$ dexamethasone, $0.5 \mathrm{mM}$ methylisobutylxanthine (IBMX), and $1 \mu \mathrm{g} / \mathrm{mL}$ insulin for two days. After $48 \mathrm{~h}$ of incubation, the differentiation medium was replaced with DMEM containing $10 \% \mathrm{FBS}$ and $1 \mu \mathrm{g} / \mathrm{mL}$ insulin [22]. Cell medium was replaced at 2-day intervals with the addition of compounds studied. Analyses were carried out 7 days after differentiation if not stated otherwise. To perform biological activity assays, a stock solution of PJ at concentration $100 \mathrm{mg} / \mathrm{mL}$ in $50 \%$ dimethyl sulfoxide (DMSO) was prepared and further dilutions were made with culture medium. The sample's concentrations used in biological studies are presented in the descriptions of the tests carried out. All cell culture experiments were performed in a humidified $5 \% \mathrm{CO}_{2}$ and $95 \%$ atmosphere at $37^{\circ} \mathrm{C}$. Tissue culture plastics were supplied by Greiner Bio-One GmbH (Frickenhausen, Austria). All the experimental measurements were performed using the Synergy 2 BioTek Microplate Reader (BioTek, Winooski, VT, USA). Microscopic observations were performed using contrast-phase and fluorescent microscope Nikon TS100 Eclipse (Nikon, Tokyo, Japan) under $200 \times$ magnification, if not stated otherwise.

\subsection{Cell Viability}

The effects of FJ and PJ on cell viability were assayed with the PrestoBlue reagent. The 3T3-L1 preadipocytes were seeded into a 96-well plate at a density of $10^{4}$ cells/well overnight. Two days after confluence, cells were treated with series of extracts concentrations for 48 hours. The final concentration of DMSO did not exceed $0.005 \%$. Then, the PrestoBlue reagent was added for $30 \mathrm{~min}$ and fluorescent signal at F530/590 nm was measured. For cell visualization, $2 \mu \mathrm{M}$ calcein AM (Thermo Fisher Scientific, Waltham, MA, USA) was directly added to the cells.

\subsection{Detection of Intracellular Reactive Oxygen Species Generation}

The 3T3-L1 preadipocytes were seeded into a 96-well plate at a density of $10^{4}$ cells/well. After the cells' treatment with extracts, the cells were washed with phosphate buffer saline (PBS) and incubated with DMEM and $10 \mu \mathrm{M}$ of dichloro-dihydro-fluorescein diacetate (DCFH-DA) dye. Fluorescence intensity at F485/530 nm was determined after 30 min incubation. Five-hundred $\mu \mathrm{M}$ tert-BOOH $(t-\mathrm{BOOH})$ was used as a positive control. The intracellular fluorescence of cells was observed after cells treatment with chemicals under a fluorescence microscope.

\subsection{Determination of Lipid Accumulation, Free Fatty Acid Uptake and Triglyceride Content}

The 3T3-L1 preadipocytes were seeded into a 96-well plate at a density of $10^{4}$ cells/well for each of the experiment. The lipid content in the mature adipocytes was determined using the Nile red staining method. After cell incubation with FJ and PJ, cells were washed with cold PBS and fixed in $5 \%$ paraformaldehyde for $30 \mathrm{~min}$. Then, the cells were stained with Nile red $(1 \mu \mathrm{g} / \mathrm{mL})$ for $40 \mathrm{~min}$ and fluorescence intensity at F485/530 nm was measured. For cell nuclei visualization, to fixed cells, $1 \mu \mathrm{g} / \mathrm{mL}$ 4',6-Diamidine-2' -phenylindole dihydrochloride (DAPI) stain was added. The measurement of fatty acid fluorescent probe TF2-C12 uptake by cells was performed with the Fatty Acid Uptake Kit (Sigma-Aldrich, Seinheim, Germany). After the cells' treatment with the preparations, the fluorescent signal at F485/530 $\mathrm{nm}$ was measured after $1 \mathrm{~h}$ incubation with fluorescent analogue.

Triglyceride content was measured using the Triglyceride Colorimetric Assay kit (Cayman Chemical, Ann Arbor, MI, USA). To perform the experiment cells were seeded into a 6-well plate at a 
density of $2 \times 10^{5}$ cells/well. Following treatment, the differentiated 3T3-L1 adipocytes were rinsed with PBS, harvested with a cell scraper, lysed with 1\% Triton X-100 and the total triglyceride content was assessed according to the manufacturer's instructions with an absorbance measurement at $540 \mathrm{~nm}$.

\subsection{Measurement of Adipolysis}

To perform, the experiment cells were seeded into a 24-well plate at a density of $4 \times 10^{4}$ cells/well. After treatment with FJ and PJ, the cells were washed with PBS and incubated with an induction solution for $1 \mathrm{~h}$. Then the medium was collected, and glycerol released into the medium was measured at $570 \mathrm{~nm}$ using a colorimetric assay Adipolysis Assay Kit (Sigma-Aldrich, Steinheim, Germany) and following the manufacturer's instructions. As a positive control (lipolysis inducer), $10 \mu \mathrm{M}$ isoproterenol was used.

\subsection{Gene Expression Analysis}

To perform, the experiment cells were seeded into a 6-well plate at a density of $2 \times 10^{5}$ cells/well. After cell incubation with FJ and PJ, the total RNA was extracted with the GeneMatrix Universal RNA Purification Kit (Eurex Ltd., Gdansk, Poland) according to the manufacturer's procedure. RNA samples were purified with an amplification Grade DNase I (Sigma-Aldrich, Steinheim, Germany), and reverse transcribed with the NG dART RT Kit (Eurex Ltd., Gdansk, Poland). Real-time RT-PCR was carried out using the SG qPCR Master Mix (Eurex Ltd., Gdansk, Poland) on a BioRad CFX96 qPCR System (Bio-Rad, Hercules, CA, USA). Complementary DNA representing 6 ng of total RNA per sample was subjected to 40 cycles of PCR amplification. Samples were first incubated at $95{ }^{\circ} \mathrm{C}$ for $40 \mathrm{~s}$, then at $55^{\circ} \mathrm{C}$ for $30 \mathrm{~s}$, and finally at $72{ }^{\circ} \mathrm{C}$ for $30 \mathrm{~s}$. To exclude non-specific products and primer-dimers, after the cycling protocol, a melting curve analysis was performed by maintaining the temperature at $52{ }^{\circ} \mathrm{C}$ for $2 \mathrm{~s}$, followed by a gradual temperature increase to $95{ }^{\circ} \mathrm{C}$. The threshold cycle $(\mathrm{Ct})$ values for that gene did not change in independently performed experiments. The level of target gene expression was calculated as $2^{-\Delta \Delta \mathrm{Ct}}$, where $\Delta \Delta \mathrm{Ct}=[\mathrm{Ct}(\mathrm{target})-\mathrm{Ct}(\beta \mathrm{actin})]$ sample - $[\mathrm{Ct}($ target $)-\mathrm{Ct}(\beta \mathrm{actin})]$. The following primer sequences were used to determine the genes' expression: CREB-binding protein $(C B P)$ : forward primer (F) TTACAACAGGCCAGGTTTCC, reverse primer (R) GGCTGGCGACATACAGTACA; sterol regulatory element binding transcription factor 1 (SREBP1): (F) TGTTGGCATCCTGCTATCTG, (R) AGGGAAAGCTTTGGGGTCTA; -actin: (F) CCACAGCTGAGAGGGAAATC, (R) AAGGAAGGCTGGAAAAGAGC; adiponectin: (F) AGATGGCACTCCTGGAGAGAAG, (R) ACATAAGCGGCTTCTCCAGGCT; leptin: GGATCAGGTTTTGTGGTGCT, (R) TTGTGGCCCATAAAGTCCTC; fatty acid synthase (FAS): (F) TTGCTGGCACTACAGAATGC, (R) AACAGCCTCAGAGCGACAAT; peroxisome proliferator activated receptor gamma $(P P A R \gamma)$ : (F) GCGGAAGAAGAGACCTGGG, (R) AGAACGTGACTTCTCAGCCC; interleukin-6 (Il-6): (F) GTCCTTCCTACCCCAATTTCCA, (R) TAACGCACTAGGTTTGCCGA; CCAAT/enhancer binding protein $(C / E B P) \quad(F)$ GTGTGCACGTCTATGCTAAACCA, (R) GCCGTTAGTGAAGAGTCTCAGTTTG; tumor necrosis factor $\alpha(T N F \alpha)$ : (F) GGGATCTGCTCCGCGGTTGT, (R) TCCGCGGCCAGGAGAACTGT; acetyl-Coenzyme A carboxylase alpha (ACC): (F) GGGGATCTCTGGCTTACAGG, (R) ATCGCATGCATTTCACTGCT; fatty acid translocase (FAT/CD36), (F) TGGCCTTACTTGGGATTGG, (R) CCAGTGTATATGTAGGCTCATCCA.

\subsection{Western Blotting}

To perform the experiment cells were seeded into a 6-well plate at a density of $2 \times 10^{5}$ cells/well. To prepare the total cell lysates, monolayers of 3T3-L1 adipocytes were scraped and lysed in Mammalian Protein Extraction Reagent (M-PER) containing protease and phosphatase inhibitors cocktail (Thermo Scientific, Waltham, MA, USA). Then, the lysates were centrifuged at 13,000 rpm for $5 \mathrm{~min}$, and the supernatants of cell lysates were separated. The protein quantification was measured using the Protein Assay Dye Reagent Concentrate (Bio-Rad Laboratories BmbH, 
München, Germany). Each $20 \mu \mathrm{g}$ of protein samples were separated by $8 \%$ or $10 \%$ sodium dodecyl sulphate-polyacrylamide gel electrophoresis (SDS-PAGE) and transferred to $0.45 \mu \mathrm{m}$ nitrocellulose blotting membrane (GE Healthcare, Chicago, IL, USA). The membranes were blocked using 5\% bovine serum albumin (BSA) in tris-buffered saline containing 0.1\% Tween-20 (TBST) for $2 \mathrm{~h}$ at room temperature and incubated with primary antibodies overnight at $4{ }^{\circ} \mathrm{C}$ diluted 1:1000 in the same solution. Polyclonal rabbit antibodies targeting PPAR $\gamma$ (\#2435), RxR $\alpha$ (\#5388), CBP (\#7389), acetyl-CoA carboxylase (\#3676), phospho-acetyl-CoA carboxylase (Ser79) (\#3661), phospho-AMPK $\alpha$ (Thr172) (\#2531) and $\beta$ actin (\#4967) were purchased from Cell Signaling Technology (Danvers, MA, USA), SREBP-1c (14088-1-AP) from Proteintech Group (Manchester, UK), and p-IRS-1 (Ser307) from Santa Cruz Biotechnology (Dallas, TX, USA). Afterwards, the membranes were washed three times with TBST, then incubated for $1 \mathrm{~h}$ at room temperature with horseradish peroxidase (HRP)-conjugated secondary anti-rabbit antibody (\#7074, Cell Signaling Technology, Danvers, MA, USA) diluted 1:3000 in 5\% nonfat dry milk in TBST. After that membranes were rewashed three times with TBST. The proteins were visualized using an enhanced chemiluminescent SuperSignal West Pico Trial Kit (Thermo Scientific, Waltham, MA, USA). The ChemiDocTM MP Image System with Image LabTM 5.1 software (Bio-Rad Laboratories, Hercules, CA, USA) was used for acquisition and densitometric analysis of western blot images. Relative protein band intensity was normalized to $\beta$-actin and quantified with respect to control cells.

\subsection{Determination of Selected Proteins Levels}

To perform, the experiment cells were seeded into a 6-well plate at a density of $2 \times 10^{5}$ cells/well. On the last day of cells treatment the medium was collected and protein concentrations of adiponectin (Adiponectin Mouse ELISA Kit, Abcam, Cambridge, GB), leptin (Leptin Mouse ELISA Kit, Abcam, Cambridge, GB), Il6 (Mouse IL6 ELISA kit, Biorbyt Ltd., Cambridge, GB) and TNF $\alpha$ (Mouse TNF alpha ELISA kit, Biorbyt Ltd., Cambridge, GB), were determined using ELISA kits, following the manufacturer's instructions. The PPAR $\gamma$ protein level present in the nuclear fraction of the cellular lysates was determined with the PPAR $\gamma$ Transcription Factor Assay Kit (Abcam, Cambridge, GB).

\subsection{Reporter Gene Assay}

Cellular activation of the PPAR $\gamma$ nuclear receptor was assessed in the reporter gene assay GeneBLAzer®PPAR gamma 293H DA (Invitrogen, Carlsbad, CA, USA) according to the manufacturer's protocol. In brief, cells stably expressing specific PPAR $\gamma$ ligand-binding domain fusion protein and UAS- $\beta$-lactamase reporter gene were incubated with tested extracts for $16 \mathrm{~h}$, the cells were loaded with cell-permeable LiveBLAzer FRET B/G substrate, after $2 \mathrm{~h}$ incubation fluorescence intensities at 460 and $530 \mathrm{~nm}$ emission following excitation at $420 \mathrm{~nm}$ were measured. After subtraction of fluorescence background from cell-free wells, the ratio of fluorescence intensity at 460 versus $530 \mathrm{~nm}$ was calculated. As the PPAR $\gamma$ inhibitor $0.1 \mu \mathrm{M}$ T0070907 was used, whereas $1 \mu \mathrm{M}$ rosiglitazone as the activator.

\subsection{Molecular Modeling}

To determine the potential interaction between analyzed FJ or PJ components and the PPAR $\gamma$ receptor, molecular docking simulation was performed. An X-ray crystal structure for human PPAR $\gamma$ receptor in complex with rosiglitazone (5YCP) was obtained from the Protein Data Bank database (http://www.rcsb.org/) as a .pdb file [24]. Subsequently, the protein molecule model was prepared to docking procedure (hydrogen addition and grid box coordinates determination) with the AutoDock Tolls software. Then the protonation state of the side chains was defined with the PROPKA software (available at http://nbcr-222.ucsd.edu/pdb2pqr_2.0.0/). Structures of rosiglitazone, chlorogenic acid, and (+)- catechin were downloaded from the ZINC database (http://zinc.docking.org/substances/ home/). The procyanidin B1 and C1 structures were built with ChemSkech software. The obtained files were converted to .pdb file with the OPENBABEL tools http://www.cheminfo.org/Chemistry/ Cheminformatics/FormatConverter/index.html). Then, all the ligand molecules were prepared for 
further modeling (determine rotating bonds) with the AutoDock Tools and saved as .pdbqt file. The docking of the prepared ligand to PPAR $\gamma$ receptor was performed with Autodock Vina docking software. [AutoDock Vina: improving the speed and accuracy of docking with a new scoring function, efficient optimization and multithreading]. The size of the grid box was set to $34 \times 30 \times 30 \AA$ from the center of the binding pocket. The value of the exhaustiveness parameter was set to 150 . Images of the docked ligands were shown with the use of the AutoDock Tools software.

\subsection{Statistical Analysis}

Unless stated otherwise, all the biological results are presented as means of 3-6 repeated experiments \pm SEM. All calculations were evaluated for significance using one-way ANOVA followed by Dunnett's test with the GraphPad Prism 6.0 software (GraphPad Software, Inc., La Jolla, CA, USA). $p \leq 0.05$ was considered statistically significant.

\section{Results and Discussion}

\subsection{Identification and Content of Phenolic Compounds in V. opulus FJ and PJ with the UPLC-PDA-Q/TOF-MS Method}

The results of the qualitative and quantitative analysis of $V$. opulus FJ and PJ determined by the UPLC/MS method are presented in Figure 1 and Tables 1 and 2. A total of 29 and 30 phenolic compounds were positively identified in FJ and PJ, respectively, on the basis of the complementary information provided by PDA and the ESI-MS detection, and literature data. The FJ and PJ showed the presence of different groups of phenolic compounds, such as hydroxycinnamic acids, flavanols, flavonols, and anthocyanins. Significant differences $(p \leq 0.05)$ in the content of individual phenolic compounds between FJ and PJ were noted as a result of about a 90-fold increase in the content of phenolics in PJ ( $878.6342 \mathrm{mg} / \mathrm{g})$ compared to FJ $(11.508 \mathrm{mg} / \mathrm{g})$. Thus, it could be concluded that the Solid-Phase Extraction (SPE) method on a Sep-Pak C18 column is efficient for removing non-phenolic compounds from the juice. In the published studies, total phenolic determined by the Folin-Ciocalteu method content in the $V$. opulus fruit juices varied from 5.47 to $11.70 \mathrm{mg} / \mathrm{g}$ [25].

Hydroxycinnamic acids were the most predominant phenolic group found in both samples and constituted $80.46 \%$ and $77.50 \%$ of the sum of the phenolics in PJ and FJ, respectively. Chlorogenic acid (peak 9) with the negative molecular ion [M - H]- of 353 with typical fragments of quinic acid ester $(\mathrm{m} / \mathrm{z}$ at 191) showed the highest content, both among phenolic compounds and hydroxycinnamic acids. Its concentrations were $645.492 \mathrm{mg} / \mathrm{g}$ and $8.039 \mathrm{mg} / \mathrm{g}$ in PJ and FJ, respectively. Chlorogenic acid, as the main phenolic compound in fresh berries of V. opulus and also in fresh juice, have been reported previously, where it constituted more than $96.2 \%$ of hydroxycinnamic acid derivatives [1-4]. Quantitatively, a second compound from hydroxycinnamic acids identified in FJ and PJ was caffeoylquinic acid (peak 13) with the negative molecular ion [M - H]- of 353 and fragment ions $\mathrm{m} / \mathrm{z}$ at 191, 133. Additionally, two caffeoylquinic acids with the known structures, such as neochlorogenic acid (peak 1) and cryptochlorogenic acid (peak 10), were identified. Besides, five caffeoylquinic acid derivatives (peaks 3, 4, 7, 21, 22) were present in both samples. On the other hand, feruloylquinic acids (peaks 24 and 27) were only identified in PJ. Quantitatively, the second phenolic subgroup of phenolics was flavanols, which constituted 19.52 and $16.30 \%$ of FJ and PJ total phenolics, respectively (Table 2). The main flavan-3-ol isomers were (+)-the catechin (peak 6) and procyanidin dimer B1 (peak 2). Also, the procyanidin dimer B2 (peak 11) and procyanidin trimer C1 (peak 17) were identified in both samples based on reference substances. Furthermore, other procyanidin dimer and trimer, which were identified previously, were presented in our samples [26]. 


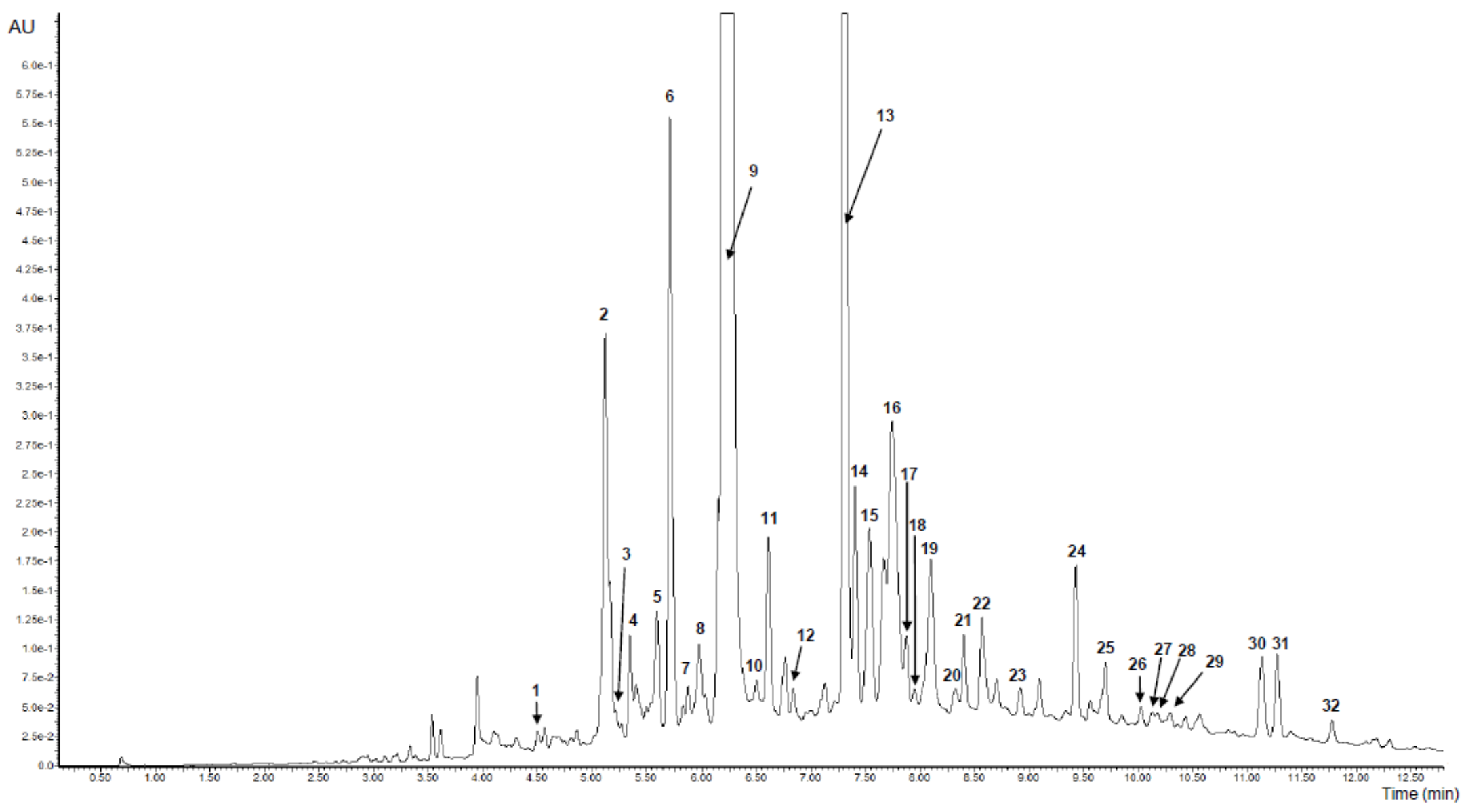

Figure 1. UPLC chromatogram of purified V. opulus juice (PJ) at $280 \mathrm{~nm}$. Refer to Table 1 for the identification of each numbered peak. 
Table 1. Retention time (Rt), wavelengths of maximum absorption ( $\lambda$ max), mass spectral data, and the identification and quantification of phenolic compounds in fresh juice and purified juice of Viburnum opulus fruit.

\begin{tabular}{|c|c|c|c|c|c|c|c|}
\hline \multirow{2}{*}{ Peak No. } & \multirow{2}{*}{ Phenolic Compound } & \multirow{2}{*}{$\mathbf{R}_{\mathrm{t}}(\min )$} & \multirow{2}{*}{$\lambda_{\max }(\mathrm{nm})$} & \multirow{2}{*}{$\underset{(\mathrm{m} / \mathrm{z})}{[\mathrm{M}-\mathrm{H}]^{-} /[\mathrm{M}+\mathrm{H}]^{+}}$} & \multirow{2}{*}{$\begin{array}{l}\text { Fragment(s) Ions } \\
(\mathrm{m} / \mathrm{z})\end{array}$} & \multicolumn{2}{|c|}{ Content (mg/g) } \\
\hline & & & & & & Fresh Juice (FJ) & Purified Juice (PJ) \\
\hline 1 & Neochlorogenic acid ${ }^{1}$ & 4,50 & 318 & 353 & 191,179 & $0.007 \pm 0.001$ & $0,215 \pm 0.019$ \\
\hline 2 & Procyanidin dimer B1 ${ }^{1}$ & 5.12 & 276 & 577 & 407,289 & $0.759 \pm 0.003$ & $47.596 \pm 0.148$ \\
\hline 3 & $\begin{array}{l}\text { Caffeoylquinic acid } \\
\text { derivative } \mathrm{I}^{2}\end{array}$ & 5.17 & 323 & 707 & 191 & $0.015 \pm 0.000$ & $1.289 \pm 0.058$ \\
\hline 4 & $\begin{array}{l}\text { Caffeoylquinic acid } \\
\text { derivative II }{ }^{2}\end{array}$ & 5.35 & 323 & 707 & 191 & $0.024 \pm 0.002$ & $1.051 \pm 0.008$ \\
\hline 5 & Procyanidin trimer $\mathrm{I}^{3}$ & 5.60 & 278 & 865 & $577,289,243$ & $0.112 \pm 0.001$ & $6.866 \pm 0.342$ \\
\hline 6 & $(+)$-Catechin ${ }^{1}$ & 5.70 & 278 & 289 & 245,202 & $0.657 \pm 0.006$ & $40.729 \pm 0.596$ \\
\hline 7 & $\begin{array}{l}\text { Caffeoylquinic acid } \\
\text { derivative III }{ }^{2}\end{array}$ & 5.74 & 323 & 707 & 191 & $0.017 \pm 0.001$ & $1.220 \pm 0.020$ \\
\hline 8 & Procyanidin trimer II ${ }^{3}$ & 5.87 & 275 & 865 & $577,289,243$ & $0.030 \pm 0.006$ & $2.634 \pm 0.270$ \\
\hline 9 & Chlorogenic acid $^{1}$ & 6.20 & 318 & 353 & $191,707^{a}$ & $8.039 \pm 0.145$ & $645.492 \pm 1.984$ \\
\hline 10 & Cryptochlorogenic acid $^{1}$ & 6.50 & 323 & 353 & 191,173 & $0.004 \pm 0.000$ & $0.484 \pm 0.023$ \\
\hline 11 & Procyanidin dimer B2 ${ }^{1}$ & 6.61 & 278 & 577 & 407,289 & $0.199 \pm 0.002$ & $11.540 \pm 0.148$ \\
\hline 12 & Gallocatechin gallate ${ }^{4}$ & 6.84 & 280 & 457 & 169 & $0.031 \pm 0.000$ & $1.876 \pm 0.085$ \\
\hline 13 & Caffeoylquinic acid ${ }^{4}$ & 7.31 & 313 & 353 & $191,133,707^{\mathrm{a}}$ & $0.745 \pm 0.001$ & $44.344 \pm 0.176$ \\
\hline 14 & (-)-Epicatechin ${ }^{1}$ & 7.40 & 278 & 289 & 245,202 & $0.135 \pm 0.002$ & $8.002 \pm 0.116$ \\
\hline 15 & Cyanidin-3-sambubioside ${ }^{1}$ & 7.53 & 515 & $581^{+}$ & 287 & $0.093 \pm 0.000$ & $7.010 \pm 0.003$ \\
\hline 16 & Cyanidin-3-glucoside ${ }^{1}$ & 7.74 & 515 & $449^{+}$ & 287 & $0.139 \pm 0.000$ & $13.583 \pm 0.799$ \\
\hline 17 & Procyanidin dimer $\mathrm{C} 1^{1}$ & 7.86 & 278 & 865 & 407,289 & $0.033 \pm 0.001$ & $3.212 \pm 0.351$ \\
\hline 18 & $\begin{array}{l}\text { B-typeprocyanidin dimer } \\
\text { derivative } \mathrm{I}^{5}\end{array}$ & 7.96 & 276 & 739 & 577,289 & $0.016 \pm 0.000$ & $2.071 \pm 0.097$ \\
\hline 19 & Cyanidin-3-rutinoside $^{1}$ & 8.10 & 516 & $595^{+}$ & 287 & $0.068 \pm 0.001$ & $5.072 \pm 0.016$ \\
\hline 20 & 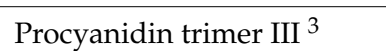 & 8.32 & 278 & 865 & $577,289,243$ & $0.032 \pm 0.000$ & $1.796 \pm 0.053$ \\
\hline
\end{tabular}


Table 1. Cont.

\begin{tabular}{|c|c|c|c|c|c|c|c|}
\hline \multirow{2}{*}{ Peak No. } & \multirow{2}{*}{ Phenolic Compound } & \multirow{2}{*}{$\mathbf{R}_{\mathbf{t}}(\min )$} & \multirow{2}{*}{$\lambda_{\max }(\mathrm{nm})$} & \multirow{2}{*}{$\underset{(\mathrm{m} / \mathrm{z})}{[\mathrm{M}-\mathrm{H}]^{-} /[\mathrm{M}+\mathrm{H}]^{+}}$} & \multirow{2}{*}{$\begin{array}{l}\text { Fragment(s) Ions } \\
(\mathrm{m} / \mathrm{z})\end{array}$} & \multicolumn{2}{|c|}{ Content (mg/g) } \\
\hline & & & & & & Fresh Juice (FJ) & Purified Juice (PJ) \\
\hline 21 & $\begin{array}{l}\text { Caffeoylquinic acid } \\
\text { derivative IV }{ }^{2}\end{array}$ & 8.40 & 325 & 705 & 513 & $0.034 \pm 0.000$ & $3.306 \pm 0.014$ \\
\hline 22 & $\begin{array}{l}\text { Caffeoylquinic acid } \\
\text { derivative } \mathrm{V}^{2}\end{array}$ & 8.56 & 325 & 705 & 513 & $0.034 \pm 0.000$ & $3.268 \pm 0.010$ \\
\hline 23 & $\begin{array}{l}\text { B-type procyanidin dimer } \\
\text { derivative II }{ }^{5}\end{array}$ & 8.92 & 278 & 739 & 577,289 & $0.035 \pm 0.000$ & $2.293 \pm 0.094$ \\
\hline 24 & Feruloylquinic acid $\mathrm{I}^{3}$ & 9.43 & 325 & 367 & 193,134 & n.d. & $5.722 \pm 0.021$ \\
\hline 25 & Quercetin-3-vicianoside $^{6}$ & 9.70 & 351 & 595 & $301,300,271$ & $0.020 \pm 0.000$ & $1.266 \pm 0.007$ \\
\hline 26 & Procyanidin dimer ${ }^{3}$ & 10.03 & 278 & 577 & 407,289 & $0.024 \pm 0.001$ & $1.602 \pm 0.258$ \\
\hline 27 & Feruloylquinic acid II ${ }^{3}$ & 10.13 & 304 & 367 & 193,134 & n.d. & $0.528 \pm 0.005$ \\
\hline 28 & Quercetin-3-galactoside $^{4}$ & 10.18 & 365 & 463 & 300,271 & n.d. & $0.149 \pm 0.011$ \\
\hline 29 & Quercetin-3-rutinoside $^{1}$ & 10.29 & 344 & 609 & $301,270,151$ & $0.016 \pm 0.000$ & $0.921 \pm 0.007$ \\
\hline 30 & (Epi)catechin derivative $\mathrm{I}^{2}$ & 11.13 & 280 & 451 & 289,161 & $0.103 \pm 0.001$ & $6.998 \pm 0.221$ \\
\hline 31 & (Epi)catechin derivative II ${ }^{2}$ & 11.27 & 280 & 451 & 289,161 & $0.080 \pm 0.001$ & $6.006 \pm 0.165$ \\
\hline 32 & Quercetin-3-rhamnoside $^{4}$ & 11.78 & 344 & 447 & $301,270,255,227$ & $0.007 \pm 0.000$ & $0.491 \pm 0.002$ \\
\hline
\end{tabular}

n.d. - not detected; ${ }^{a}$ dimeric adduct. Results are expressed as a mean \pm standard deviation $(n=3)$. The values expressed differ significantly (one-way ANOVA and Duncan's test, $\left.p \leq 0.05\right)$. 1 -identification based on a comparison of retention time, UV-vis spectra (200-600 nm) and MS data for standards; 2,3,4,5-identification based on a comparison of molecular ions and typical ion fragments with published data; $2-[6], 3-[7], 4-[8], 5-[9], 6-[10]$. 
Table 2. The total content of the different phenolic groups in $V$. opulus fresh juice and purified juice according to UPLC-PDA-Q/TOF-MS analysis.

\begin{tabular}{ccc}
\hline \multirow{2}{*}{ Group of Phenolics } & \multicolumn{2}{c}{ Total Content (mg/g) } \\
\cline { 2 - 3 } & Fresh Juice (FJ) & Purified Juice (PJ) \\
\hline Flavanols & $2.246 \pm 0.014$ & $143.210 \pm 1.377$ \\
\hline Hydroxycinnamic acids (HCA) & $8.919 \pm 0.146$ & $706.919 \pm 2.119$ \\
\hline$>$ Flavonols & $0.043 \pm 0.000$ & $2.827 \pm 0.026$ \\
\hline Anthocyanins & $0.301 \pm 0.002$ & $25.665 \pm 0.812$ \\
\hline Total phenolics & $11.508 \pm 0.154$ & $878.632 \pm 2.722$ \\
\hline
\end{tabular}

Results are expressed as a mean \pm standard deviation $(n=3)$. The values differ significantly (one-way ANOVA and Duncan's test, $p \leq 0.05)$.

V. opulus fruits are characterized by varied content of anthocyanins, with cyanidin glycosides, such as glucoside, rutinoside and sambubioside as the main pigments [15,27]. In the tested FJ and PJ, cyanidin-3-glucoside (peak 16) was the main anthocyanin with the content $13.583 \mathrm{mg} / \mathrm{g}$ for PJ and $0.139 \mathrm{mg} / \mathrm{g}$ of FJ. Content of cyanidin-3-sambubioside (peak 15) and cyanidin-3-rutinoside (peak 19) were similar in both samples. The total content of anthocyanins was $0.300 \mathrm{mg} / \mathrm{g}$ of FJ and $25.665 \mathrm{mg} / \mathrm{g}$ of PJ. Perova et al. identified ten cyanidin glycoside in $V$. opulus fruits with cyanidin-3-glucoside and cyanidin-3-xylosyl-rutinoside as the main compounds [15]. Among the phenolic compounds estimated, flavonols occurred at the lowest concentration with $2.827 \mathrm{mg} / \mathrm{g}$ of PJ and only $0.043 \mathrm{mg} / \mathrm{g}$ of FJ (Table 2). V. opulus PJ and FJ contained quercetin-3-vicianoside (peak 25), quercetin-3-rutinoside (peak 29), quercetin-3-rhamnoside (peak 32) and quercetin-3-galactoside (peak 28), whereas the latter has not been determined in FJ. There are reports that also isorhamnetin glycosides have been found in V. opulus fruit and juice $[15,18]$.

\subsection{Inhibition of Pancreatic Lipase by V. opulus FJ and PJ}

Pancreatic lipase (EC 3.1.1.3; triacylglycerol acyl hydrolase) breaks down TAG into absorbable monoacylglycerols and free fatty acids. Pancreatic lipase is responsible for the hydrolysis of $50-70 \%$ of total dietary fats in the intestinal lumen [28]; thus, its inhibition could reduce the storage of body fat in the adipose tissues. In the present study, the effect of FJ and PJ on pancreatic lipase was determined in a triolein emulsion by the spectrophotometric method with a copper reagent. This lipid substrate is a triglyceride formed by esterification of the three hydroxy groups of glycerol with oleic acid. As shown in Figure 2, both V. opulus samples exhibited a dose-dependent inhibitory effect on pancreatic lipase activity. The concentration of PJ inhibiting lipase activity to $50 \%$ was equal to $55.26 \pm 2.54 \mathrm{mg} / \mathrm{mL}$ and showed 4.7-fold higher inhibitory activity than $\mathrm{FJ}\left(\mathrm{IC}_{50}=261.94 \pm 2.00 \mathrm{mg} / \mathrm{mL}\right)$. All these samples were less potent in pancreatic lipase inhibiting than Orlistat (a well-known anti-lipase agent). The $\mathrm{IC}_{50}$ value for lipase inhibition for Orlistat was $0.380 \pm 0.004 \mu \mathrm{g} / \mathrm{mL}$. The lower anti-lipase activity of plant extracts than Orlistat is associated with the presence of other components in the extracts that do not affect the activity of the enzyme. In addition, fruit juice contains several classes of phenolic compounds, which in combination might differently affect the lipase activity due to the different interactions between them, as well as with other fruit components. 

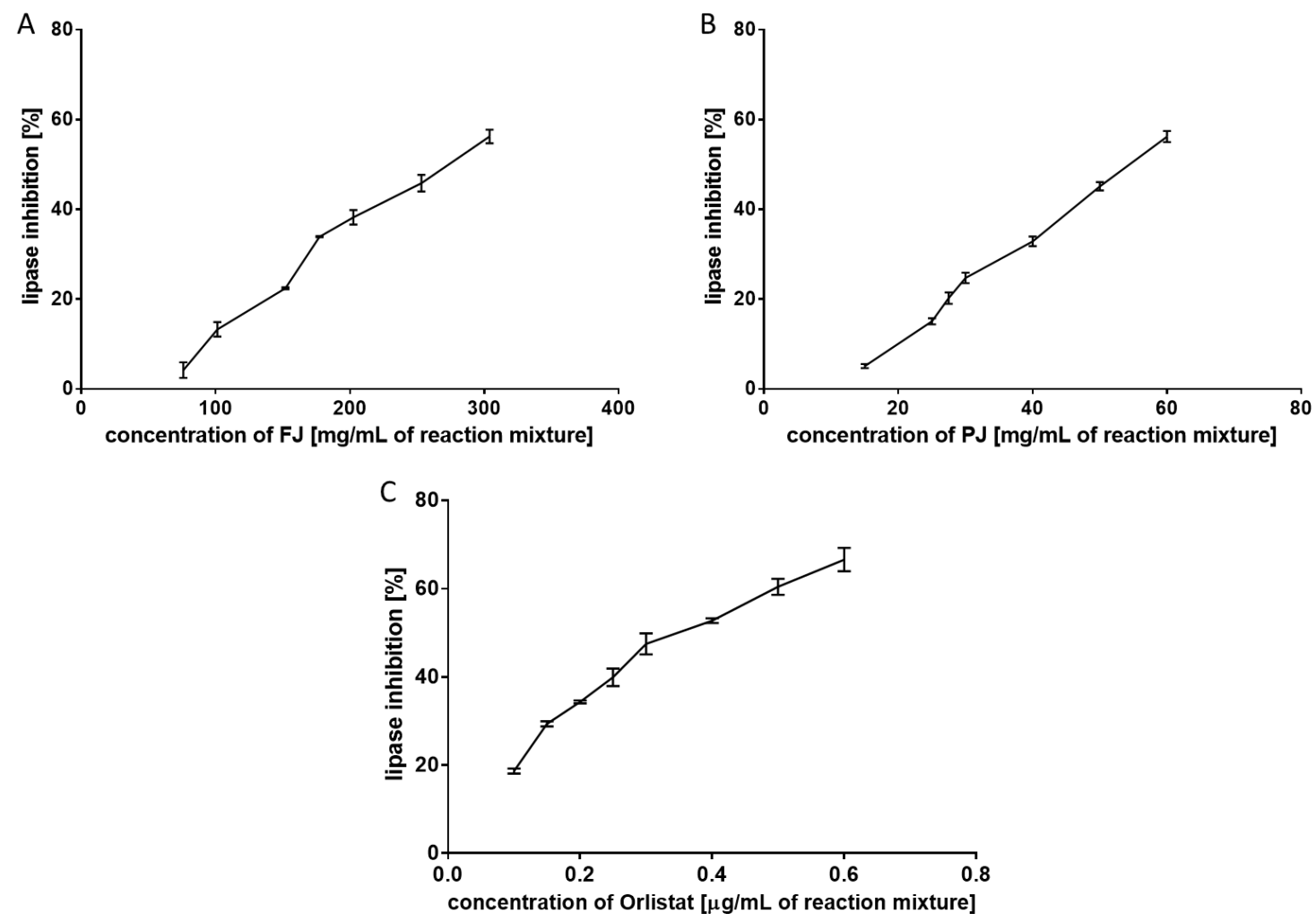

Figure 2. Inhibitory effect of fresh juice (FJ) (A), purified juice (PJ) (B), and Orlistat (C) on pancreatic lipase. Data are means of triplicate assays \pm standard deviations.

In contrast to the widely studied various fruits, literature data on the anti-lipase activity of juices and drinks are scarce. Gironés-Vilaplana et al. demonstrated a significant increase in isotonic citric acid drink and isotonic lemon juice drinkability to inhibit pancreatic lipase after enriching them in açai, blackthorn or maqui berries [29]. Magui berry exhibited the most potent inhibitory activity, and the anti-lipase properties of the drinks were positively correlated with anthocyanins amounts. A similar relationship was found by Fabroni and others [30]. Among 13 fruit extracts, juices, plant tissues, legume seeds, cereals, and vegetables, "Moro" orange juice with the highest anthocyanin content, had the strongest inhibitory effect on pancreatic lipase. The orange juice lipase inhibition $\mathrm{IC}_{50}$ value of $0.46 \mathrm{mg} / \mathrm{mL}$ was higher than the $\mathrm{IC}_{50}$ of Orlistat $(0.064 \mathrm{mg} / \mathrm{mL})$. In the present study, anthocyanins constituted only 2.61 and $2.92 \%$ of the sum of the phenolics in FJ and PJ, respectively. Chlorogenic acid, quantitatively the main phenolic compounds in both samples, has also been demonstrated as a pancreatic lipase inhibitor with an $\mathrm{IC}_{50}$ value of $286.5 \mu \mathrm{M}$, however it has rather weak inhibitory potential compared to orlistat with an $\mathrm{IC}_{50}=1.2 \mu \mathrm{M}$ [31]. On the other hand, Worsztynowicz et al. demonstrated that chlorogenic acids isolated from chokeberry fruit did not inhibit the pancreatic lipase [32]. Some authors suggest that the inhibition of the pancreatic lipase by fruits is attributed to proanthocyanidins $[23,28,33]$. This group of polyphenols constituted $19.52 \%$ and $16.30 \%$ of the sum of the phenolics in FJ and PJ, respectively. Most likely, the anti-lipase potential of fruit extracts and juices, which are characterized by a complex phenolic composition, is the result of their mutual interactions. Other components of the samples analyzed may also influence their inhibitory activity toward pancreatic lipase. In the present study, $\mathrm{IC}_{50}$ values for lipase inhibition by FJ and PJ differed almost five times, despite the fact that PJ showed almost a ninety times higher concentration of phenolic compounds than FJ. 


\subsection{The Effects of V. opulus on Cellular Viability, Adipogenesis and Adipolysis}

To check the influence of $V$. opulus on the metabolic activity of 3T3-L1 cells were exposed to increasing concentrations of extracts (from 10 to $200 \mu \mathrm{g} / \mathrm{mL}$ ) for $48 \mathrm{~h}$ after reaching confluence. As is presented in Figure 3A, fresh juice inhibited cell viability by almost $35 \%$ at the highest concentration used. Dosages of FJ not exceeding $100 \mu \mathrm{g} / \mathrm{mL}$ had no cytotoxic effect on cells. Purified juice (PJ) showed higher cytotoxic potential, because its $100 \mu \mathrm{g} / \mathrm{mL}$ concentration decreased metabolic activity by almost $65 \%$ (Figure $3 \mathrm{~B}$ ). Within the dosages studied, the $\mathrm{IC}_{50}$ cytotoxicity parameter was obtained only for PJ $\left(\mathrm{IC}_{50} \approx 85 \mu \mathrm{g} / \mathrm{mL}\right.$ ). The highest non-cytotoxic concentrations $\left(\mathrm{IC}_{0}\right)$ chosen for studies of adipogenesis regulation were $100 \mu \mathrm{g} / \mathrm{mL}$ for FJ and $25 \mu \mathrm{g} / \mathrm{mL}$ for PJ, respectively.
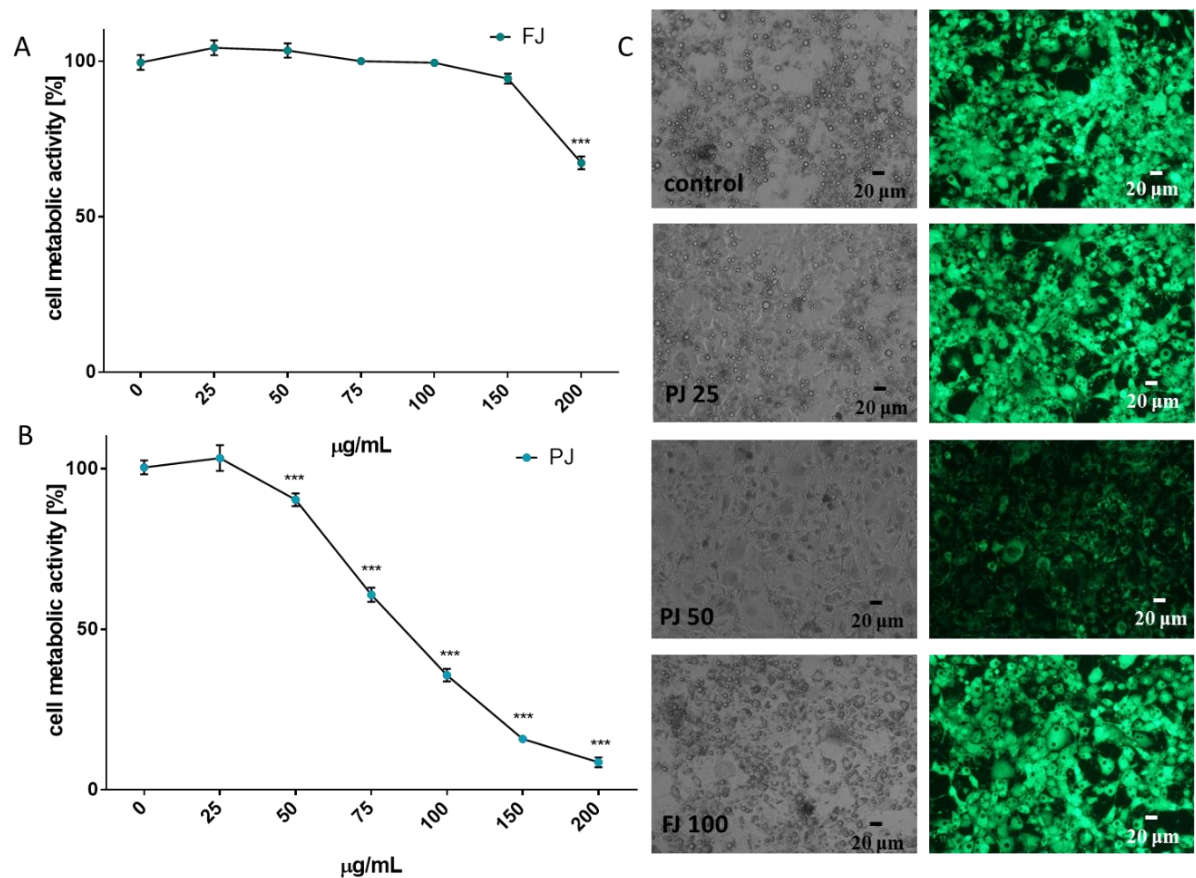

Figure 3. The influence of $V$. opulus FJ and PJ on 3T3L-1 cell metabolic activity determined by the PrestoBlue assay after $48 \mathrm{~h}$ exposure of FJ (A) and PJ (B); control cells were not exposed to any compound; values are means \pm standard deviations from at least three independent experiments, $n \geq 12$; statistical significance was calculated versus control cells (untreated), ${ }^{* * *} p \leq 0.001$. Morphology of 3T3L1 cells observed on the $5^{\text {th }}$ day of the cell differentiation process (C) with 25 and $50 \mu \mathrm{g} / \mathrm{mL}$ of $\mathrm{PJ}$, and $100 \mu \mathrm{g} / \mathrm{mL}$ of FJ; randomly chosen fields were photographed at $\times 200$ phase-contrast and a fluorescent microscope (cells stained with $2 \mu \mathrm{M}$ calcein AM).

The lack of cytotoxic effects of the $V$. opulus samples used at the $\mathrm{IC}_{0}$ concentration was also confirmed with microscopic observations of the adipocytes performed 5 days after the initiation of their differentiation (Figure 3C). Control cells appeared more rounded, had lipid droplets visible and strong cytosolic green fluorescence of calcein after staining with calcein AM ester. Simultaneously, cells incubated with PJ used in its cytotoxic concentration $(50 \mu \mathrm{g} / \mathrm{mL})$ had lower cytoplasmic esterase activity; thus, decreased green fluorescence of calcein was observed, and the cells were more irregular and elongated in their shape. The $\mathrm{IC}_{0}$ dosages obtained for $\mathrm{FJ}$ and $\mathrm{PJ}$ seem to be comparable with those previously observed for Caco-2 and MIN-6 cells; however, 3T3-L1 cells were more sensitive to the compounds studied—probably due to the longer incubation time [18,21].

The differentiation process of preadipocyte to mature adipocyte is associated with an increase of lipid droplets formation [22]. The cells staining with Nile red, a hydrophobic fluorescent dye that accumulates in neutral lipid droplets, allowed us to determine the $V$. opulus influence on cellular lipid droplets formation and accumulation (Figure 4). 
A

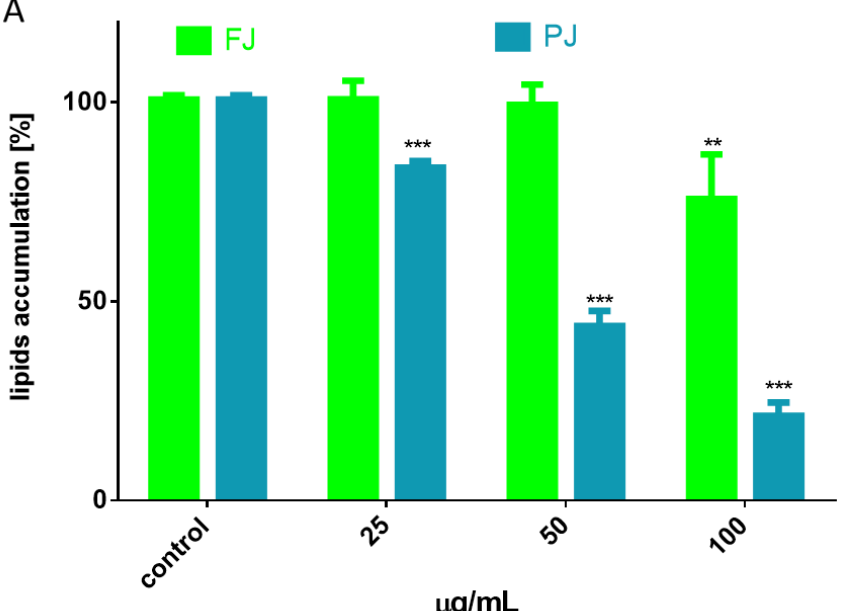

B

Nile red

DAPI
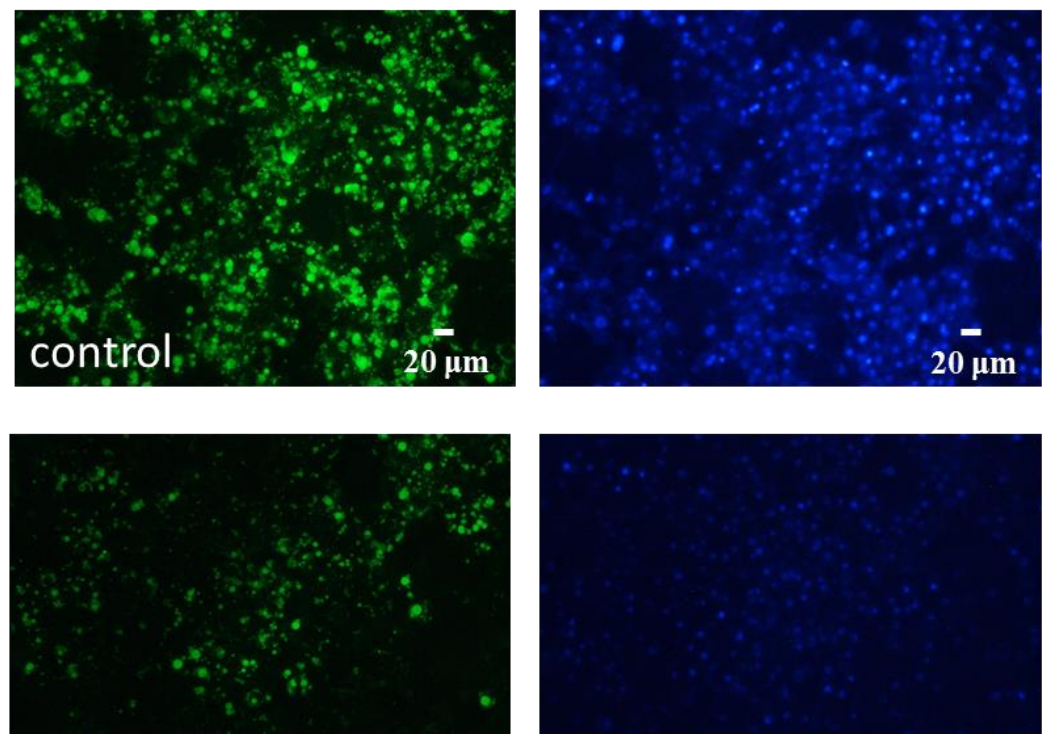

PJ 25

$20 \ddot{\mu m}$
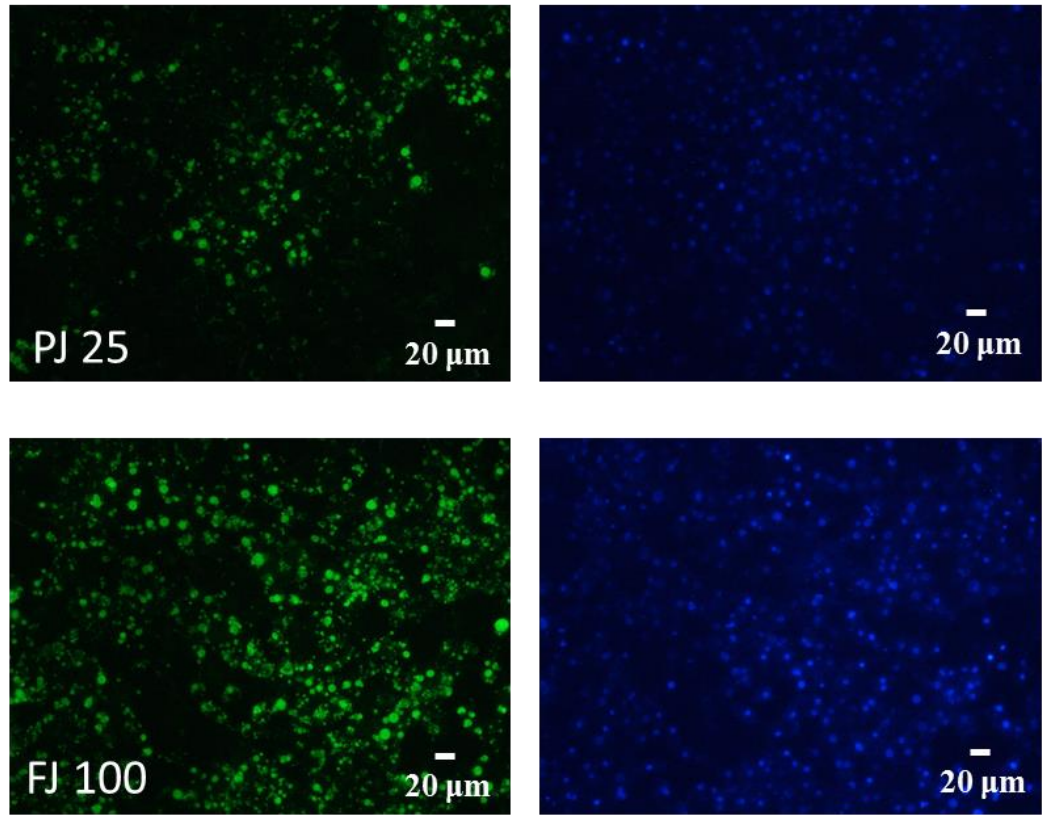

Figure 4. Influence of $V$. opulus FJ and PJ preparations on the accumulation of lipid droplets in 3T3-L1 cells stained with Nile red observed on the $7^{\text {th }}$ day of differentiation (A). The control cells were not exposed to any compound; the values are means \pm standard deviations from at least three independent experiments, $n \geq 12$; the statistical significance was calculated versus the control cells ${ }^{* *} p \leq 0.01$, *** $p \leq 0.001$. Cell lipid droplets with Nile red were visualized under a fluorescent microscope (200x magnification) (B). DAPI staining allowed for the visualization of cell nuclei with $25 \mu \mathrm{g} / \mathrm{mL}$ of PJ and $100 \mu \mathrm{g} / \mathrm{mL}$ of FJ. 
As is presented in Figure 4A, the FJ at $100 \mu \mathrm{g} / \mathrm{mL}$ significantly reduced the formation of lipid droplets compared to the control cells, whereas PJ was able to decrease lipid accumulation by $25 \%$ at $25 \mu \mathrm{g} / \mathrm{mL}$. These data were confirmed by microscopic observation (Figure 4B). As evident by Nile red staining, PJ reduced the accumulation of lipid droplets in cytoplasm, as well as the size of droplets formed was decreased. The intracellular content of TAG was also quantified. The data show that in the presence of the preparations used at $\mathrm{IC}_{0}$ dosage the level of TAG was reduced by 20-25\% (Figure 5A). It can be also seen that the PJ used at concentrations higher than $50 \mu \mathrm{g} / \mathrm{mL}$ was the most active inhibitor of lipid accumulation. However, it needs to be emphasized that observed lipid content reduction resulted from decreased cell viability (Figure 3B).
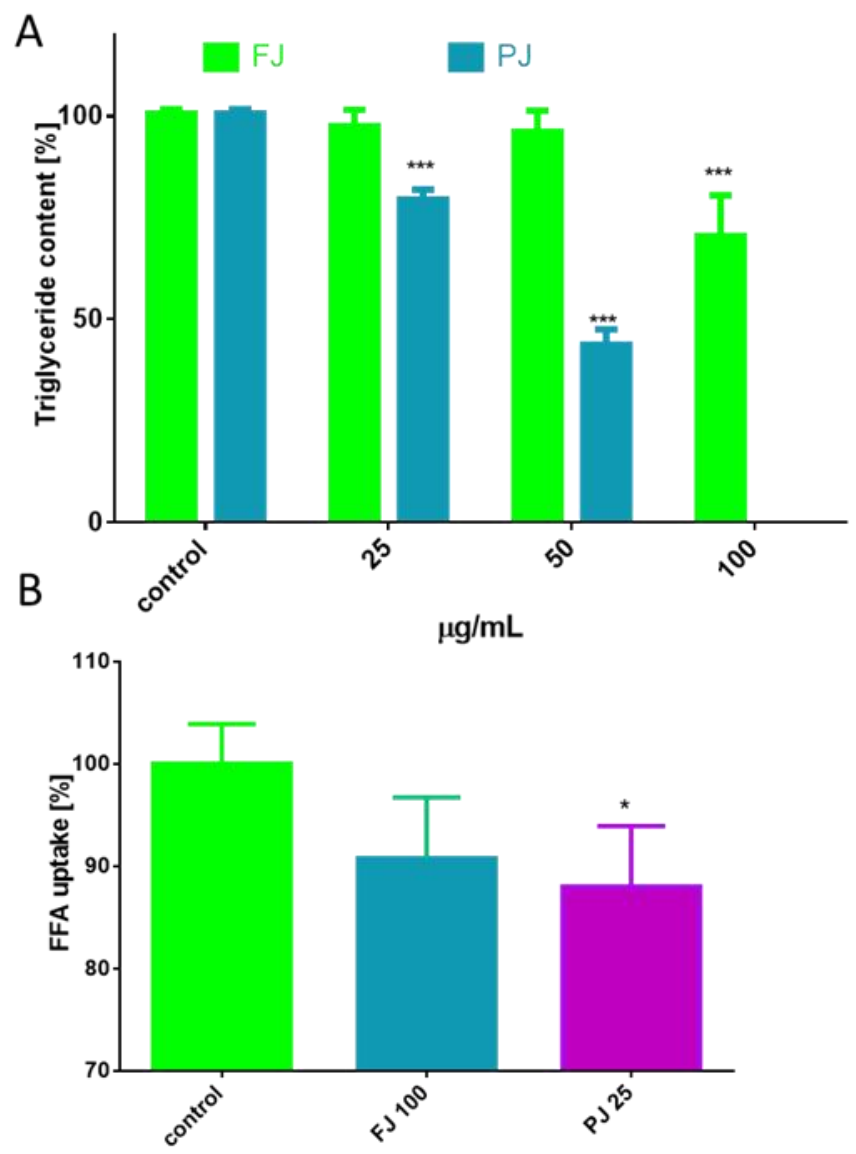

C
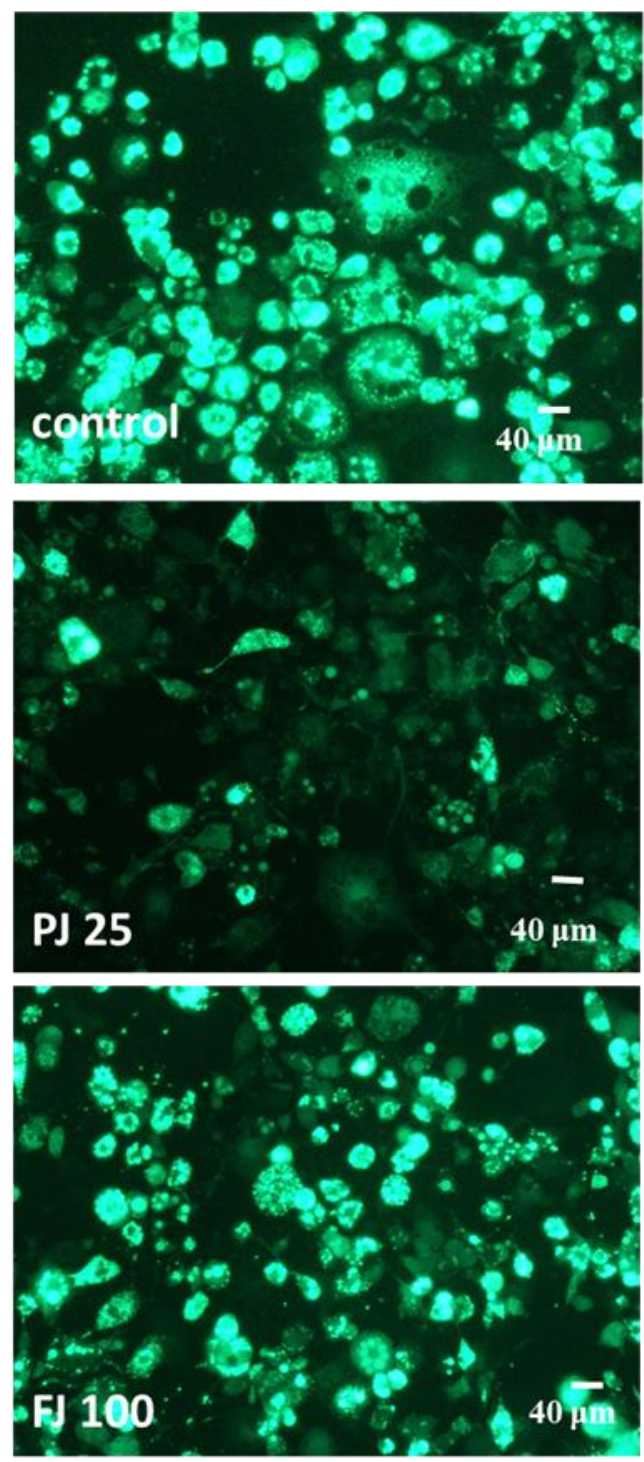

Figure 5. The influence V. opulus extracts on the triglyceride level (A) and fatty acid analog TF2-C12 uptake measured in 3T3L1 cells on the $7^{\text {th }}$ day of differentiation (B); control cells were not exposed to any compound; values are means \pm standard deviations from at least three independent experiments, $n \geq 9$; statistical significance was calculated versus control cells ${ }^{*} p \leq 0.05,{ }^{* * *} p \leq 0.001$. Cellular uptake of FFA-C12 analogue visualized under a fluorescent microscope $(400 \times$ magnification $)(C)$.

Simultaneously, the influence of FJ and PJ on cellular free fatty acid (FFA) uptake was determined. As shown in Figure 5B, the level of fluorescent free fatty acid analogue TF2-C12 incorporated in the presence of PJ was decreased by almost 10\%. Cells treated with PJ lacked strong fluorescence of 
lipid bodies, with the fluorescent analogue present mainly in the cytoplasm (Figure 5C). Collectively, it can be concluded that the purified juice of V. opulus (PJ) inhibited the adipogenic differentiation of 3T3-L1 cells.

Besides inhibiting lipogenesis, it is possible that $V$. opulus could influence the lipolysis process, which leads to the stored TAG breakdown to fatty acids and glycerol [34]. Cell incubation with preparations increased the amount of glycerol released from adipocytes, with maximal stimulation by $20 \%$ observed for $25 \mu \mathrm{g} / \mathrm{mL}$ of PJ (Figure 6), while for the FJ preparation used in $100 \mu \mathrm{g} / \mathrm{mL}$ concentration this increase was only $7 \%$. The present study provides evidence that $V$. opulus components may inhibit lipogenesis and stimulate adipolysis. The decrease in lipolysis observed in the presence of elevated dosages of PJ $(50 \mu \mathrm{g} / \mathrm{mL})$ resulted from its cytotoxic potential. Taking into account the obtained results, it can be concluded that the $V$. opulus influence is dose dependent according to the concentration of phenolic compounds. Regardless of the 90-fold higher concentration of phenolic compounds in PJ, its $\mathrm{IC}_{0}$ dose against 3T3-L1 cells is only 4-times lower than FJ. The most responsible for observed activity seems to be chlorogenic acid, which was identified as the main phenolic compound in probes. However, due to potential synergic activities and chemical interactions, other compounds present in juice, but lost during its purification process, such as procyanidins and proteins, are also responsible for the observed cellular effect. In this regard, the presented results are in agreement with our previous studies, where phenolic rich fraction from $V$. opulus fruit had stronger activity in Caco-2 and MIN6 cells $[18,21]$.

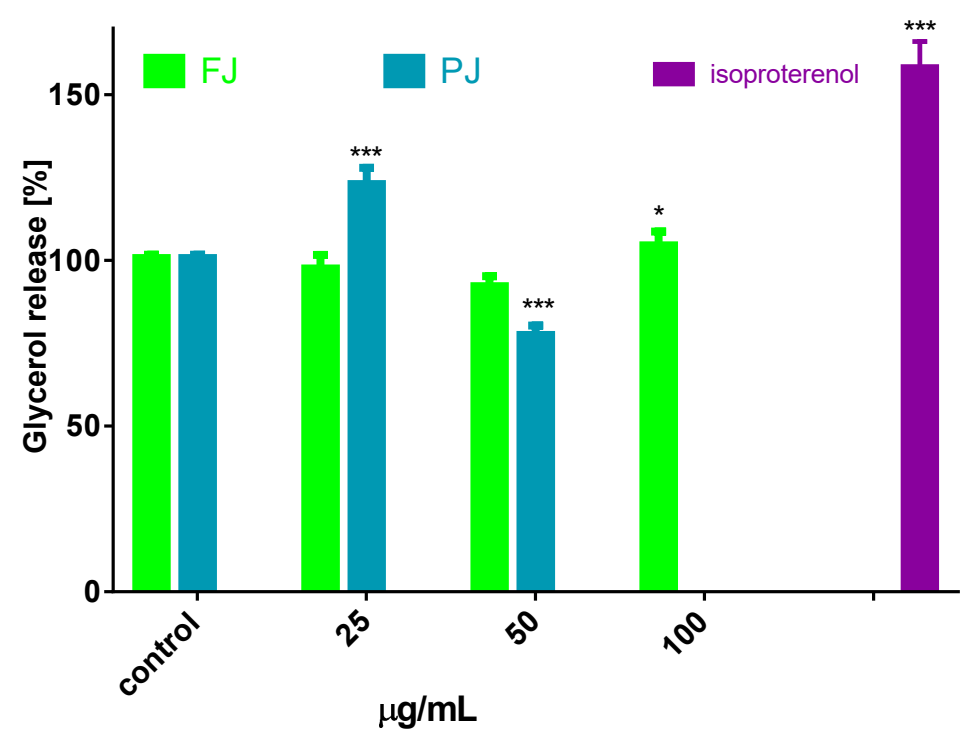

Figure 6. Lipolytic activity of V. opulus FJ and PJ preparations on differentiated 3T3L1; as a positive control $10 \mu \mathrm{M}$ isoproterenol was used; control cells were not exposed to any compound; values are means \pm standard deviations, $n=6$; statistical significance was calculated versus control cells ${ }^{*} p \leq 0.05$, $* * * p \leq 0.001$.

\subsection{The Effects of V. opulus on Expression of Genes Associated with Adipocyte Differentiation}

Differentiation of preadipocyte to adipocyte is regulated by set of transcription factors, which, upon activation, induce the expression of other adipocyte-specific genes [35]. In order to clarify the molecular effects of $V$. opulus components, the analysis of selected genes' expressions, as well as protein levels, was performed. Given the fact that V. opulus diminished lipid accumulation in 3T3-L1 cells, we first checked the effects of $\mathrm{FJ}$ and $\mathrm{PJ}$ used at the $\mathrm{IC}_{0}$ concentration on the mRNA expression of master adipogenic regulators: peroxisome proliferator-activated receptor gamma (PPAR $\gamma), \mathrm{CCAAT} /$ enhancer-binding proteins $(\mathrm{C} / \mathrm{EBP} \alpha)$ and sterol regulatory element-binding protein 1c (SREBP-1c), which have a direct impact on fat cells' development [35]. As shown in Figure 7, both samples suppressed the expression of these factors compared to untreated cells. In regard to previous studies, the purified juice rich in 
phenolic compounds presented a higher impact on 3T3-L1 cells than the fresh juice. Following PJ treatment, the PPAR $\gamma$ mRNA level decreased to $50 \%$, while C/EBP $\alpha$, CBP and SREBP-1c mRNA levels declined by $30-40 \%$. Among the genes studied, fresh juice had no impact on the changes of SREBP-1c mRNA expression, whereas a decrease in other genes' levels did not exceed $30 \%$. Furthermore, we investigated the effect of tested samples on these transcription factors' protein level. Immunoblot analysis also revealed that the PJ reduced the amount of PPAR $\gamma$ protein in adipocyte to $40 \%$ as compared to the control cells (Figure 8A). It is known that the activation of PPAR $\gamma$ protein by specific agonists results in its translocation to the nucleus, where heterodimerizes with the retinoid $x$ receptor alpha $(\mathrm{R} x \mathrm{R} \alpha)$ [35]. Thus, we decided to study a subcellular distribution of PPAR $\gamma$ receptor. The level of protein detected in the nuclear fraction of adipocytes with ELISA technique showed that, in this regard, PJ diminished PPAR $\gamma$ distribution inside the nucleus to $60 \%$ (Figure 8B). As was mentioned above, PPAR $\gamma$ transcriptional activation is initiated after its binding with the $R \times R \alpha$ receptor in the nucleus. That step of heterodimer formation describes both proteins as ligand-activated transcription factors, which coordinately regulate the gene expression of other crucial proteins involved in fatty cells differentiation, such as adipogenesis, lipid storage, lipogenesis and thermogenesis $[5,6]$. The results in Figure 8 show that FJ induced nearly 3-fold increase in $\mathrm{RxR} \alpha$ protein. This may be caused by the presence of retinoids and 9-cis-retinoic acid in studied preparations. These compounds are known precursors of carotenoids and were found to increase RxR $\alpha$ expression and activity [17,36-38]. The solid-phase purification of the FJ eliminated these compounds; thus, cells' treatment with PJ showed a $20 \%$ decrease in RxR $\alpha$ protein. Therefore, one can conclude that the observed limitation of PPAR $\gamma-\mathrm{R} x \mathrm{R} \alpha$ heterodimer formation in the cells incubated with $V$. opulus may also partially reduce adipogenesis.

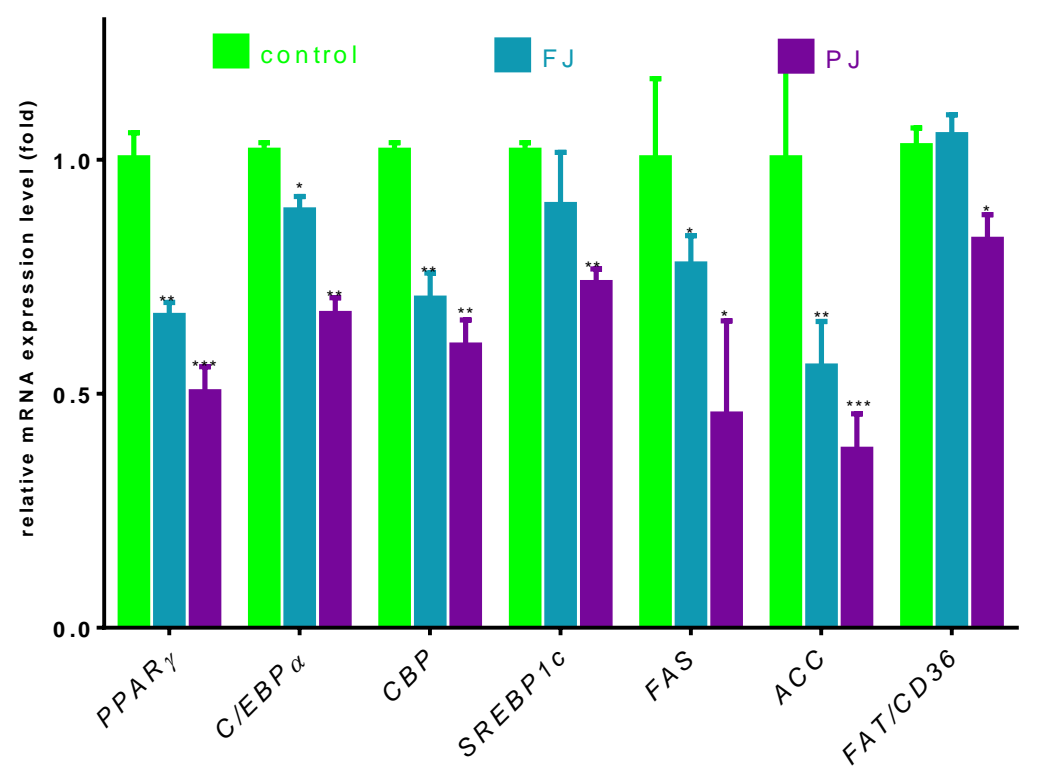

Figure 7. The influence of V. opulus FJ and PJ preparations on the gene expression in differentiated 3T3-L1 cells quantified by real-time PCR and normalized using $\beta$-actin as a reference gene. Control cells were not exposed to any compound; values are means \pm standard deviations, $n \geq 4$; statistical significance was calculated versus control cells (untreated), ${ }^{*} p \leq 0.05,{ }^{* *} p \leq 0.01,{ }^{* * *} p \leq 0.001$. 


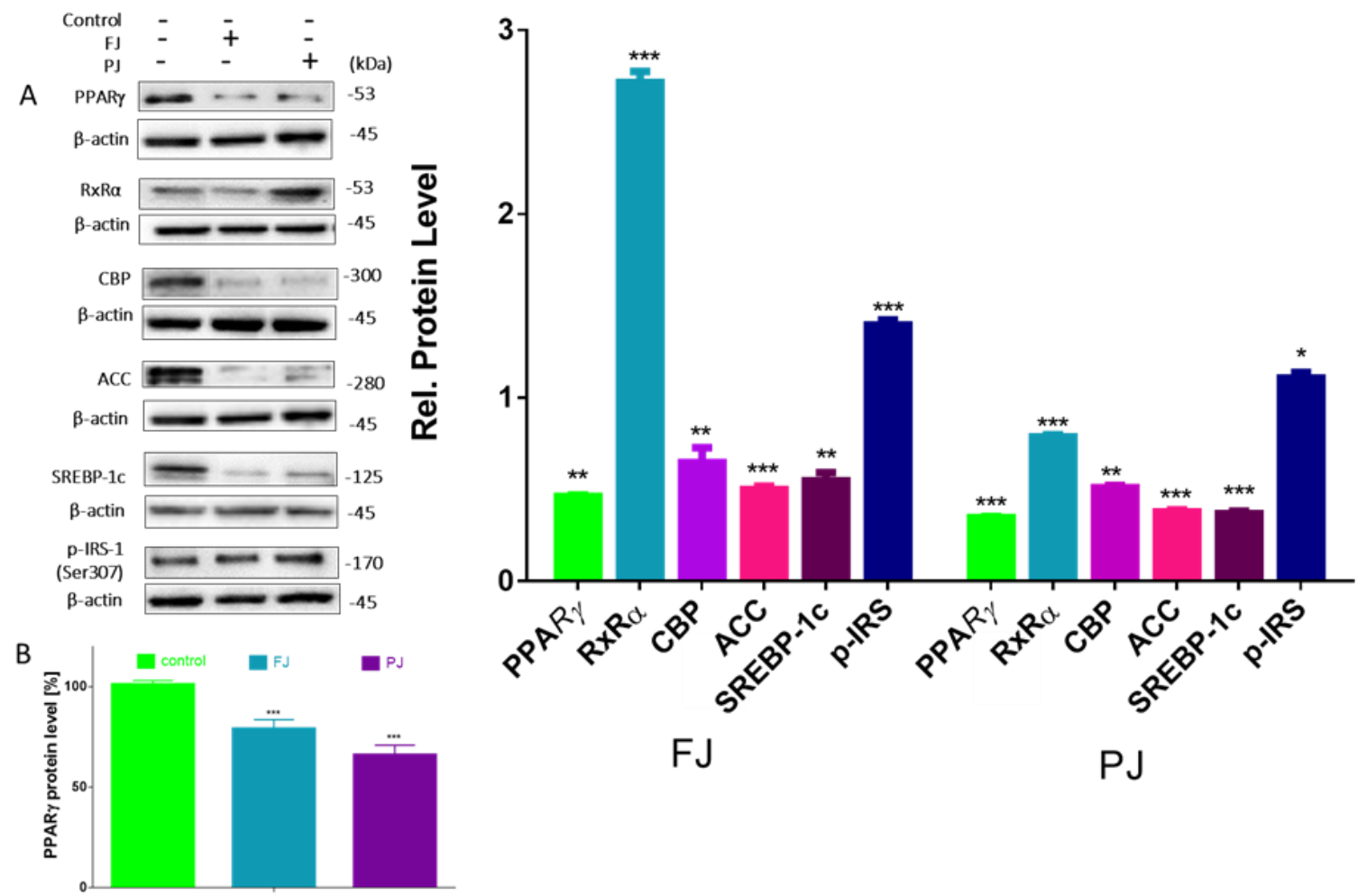

Figure 8. Effect of $V$. opulus $\mathrm{FJ}$ and PJ preparations on the relative protein level of crucial proteins involved in adipogenesis and lipogenesis determined by Western blot analysis in differentiated 3T3-L1 cells (A); the level of PPAR $\gamma$ determined with ELISA assay in nuclear fraction (B); control cells were not exposed to any compound; the values are means \pm standard deviations, $n \geq 5$; statistical significance was calculated between treatment and control cells (untreated), ${ }^{*} p \leq 0.05,{ }^{* *} p \leq 0.01,{ }^{* * *} p \leq 0.001$.

Regardless of this, it was also demonstrated that CREB-binding protein (CBP) after its activation binds to the promoter of the C/EBP gene being transcriptional coactivator that associates with PPAR $\gamma$. It has been demonstrated that IBMX and cyclic-AMP (cAMP) analogs promote adipocyte differentiation via CREB phosphorylation [39]. As before, V. opulus downregulated CBP on the transcriptional and translational levels (Figures 8 and 9); however potential CREB phosphorylation via the cAMP-dependent pathway needs to be further elucidated.

Next, we investigated the effect of $V$. opulus FJ and PJ on the expression of genes that are up-regulated during adipocyte differentiation and controlled by the abovementioned transcription factors. Fatty acid synthase (FAS) is involved in the de novo synthesis of long-chain fatty acids; thus, FAS inhibition has been considered as one of the major factors decreasing the amount of intracellular fatty acids and lipogenesis [40]. While we have not directly checked the V. opulus influence on FAS enzymatic activity, the significant downregulation of FAS expression by both preparations was detected (Figure 7). This effect was, again, slightly stronger for the PJ than for the FJ preparation $(0.55$ and 0.49 , respectively). In addition, 3T3-L1 cells' incubation with PJ influenced the mRNA level of the FAT/CD36 gene. The protein encoded by this gene is involved in the transmembrane movement of fatty acids and studies performed on CD36 knockout mice showed decreased fatty acids uptake by adipocytes [41]. According to the data presented in Figure 7, the 3T3-L1 cells incubated with PJ showed that FAT/CD36 expression decreased by $20 \%$, which matches that mechanism with previously observed diminished cellular FFA uptake. Furthermore, the reduction in SREBP-1c protein expression results in the inhibition of the expression of the enzyme catalyzing synthesis of the malonyl-CoA involved in fatty acid and triglyceride synthesis-acetyl-CoA carboxylase (ACC) [42]. The levels of the gene and ACC protein expression were decreased by almost 50\% (Figures 7 and 8 ) and these results are in agreement with the observed decrease in lipid and TAG content in mature 3T3-L1 cells. The results 
obtained are in line with the decrease of FFA uptake observed in Caco-2 cells [18]. However, it was also presented that $V$. opulus increased FFA uptake and lipids accumulation in insulinoma MIN6 cells, which may deleteriously effect insulin secretion [19].
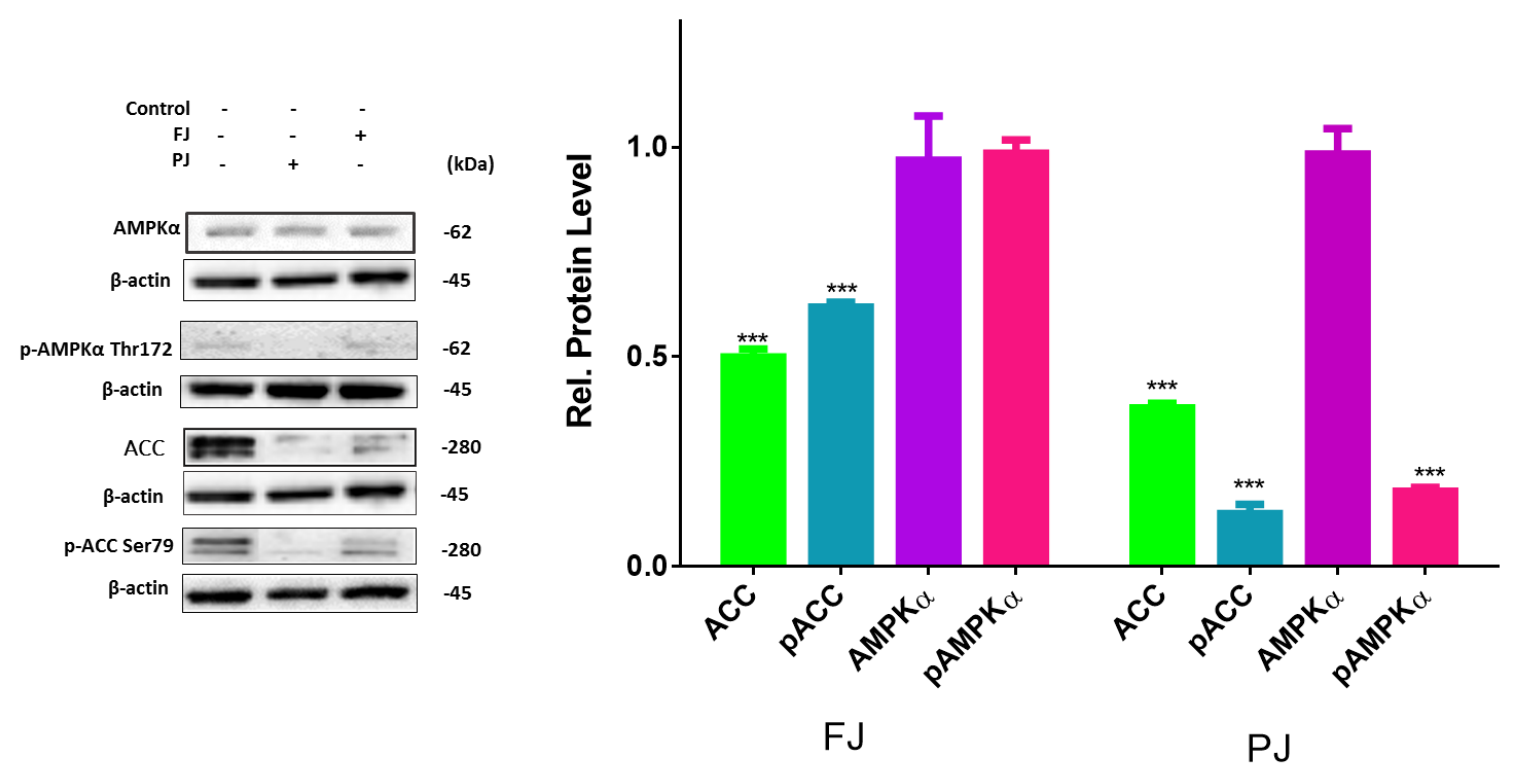

Figure 9. Effect of $V$. opulus FJ and PJ preparations on the relative levels of phosphorylated proteins involved in adipogenesis determined by Western blot analysis in differentiated 3T3-L1 cells. Control cells were not exposed to any compound; values are means \pm standard deviations, $n \geq 4$; statistical significance was calculated between treatment and control cells (untreated) with ${ }^{* * *} p \leq 0.001$.

Previous studies showed that, despite the activation of PPAR $\gamma$, the differentiation of preadipocyte can be modulated by AMP-activated protein kinase (AMPK) involvement [43]. To clarify an influence of $V$. opulus extracts on 3T3-L1 differentiation suppression we studied whether these extracts are able to activate AMPK. One of the key factors of AMPK activation is the elevation of AMP level leading to the protein $\alpha$-subunit threonine 172 phosphorylation [44]. As is shown in Figure 9, the level of total AMPK was not affected by $V$. opulus components, whereas the level of p-AMPK $\alpha$ was significantly decreased by the PJ preparation.

Among the AMPK substrates involved in the adipogenesis is acetyl-CoA carboxylase (ACC). The AMPK-catalyzed phosphorylation of ACC inhibits its enzymatic activity. While the mRNA and protein levels of ACC were decreased in cells treated with preparations, only the FJ elevated amount of phosphorylated ACC (Figure 9). In cells treated with the purified juice p-ACC level was notably diminished to $20 \%$ in comparison with the control cells (Figure 9), which is also in concordance with the observed decrease in p-AMPK level. In this regard it can be concluded that V. opulus phenolic components may inhibit activities of AMPK upstream kinases, like tumor-suppressor liver kinase B1 (LKB1), calcium-dependent calcium/calmodulin-dependent protein kinase kinase $\beta$ (CaMKK $\beta)$ and transforming growth factor- $\beta$ activated protein kinase-1 (TAK1), or activate mechanism independent of AMPK [45].

\subsection{The Effects of V. opulus on Intracellular Reactive Oxygen Species Production and Selected Adipokines and Cytokines Secretion}

During the adipogenesis and adipocyte enlargement, the intracellular reactive oxygen species (ROS) generation by the mitochondria is intensified and contributes to energy metabolism [8]. Thus, we analyzed the influence of FJ and PJ on intracellular ROS formation. As is illustrated in Figure 10A, the $V$. opulus both samples used at the $\mathrm{IC}_{0}$ dosages decreased oxidation status in adipocytes by $10-15 \%$ as compared to the control cells. Observations with the fluorescence microscopy of cells stained 
with fluorogenic dichloro-dihydro-fluorescein diacetate (DCFH-DA) correspond to the presented quantitative results (Figure 10B). This cytoprotective activity may be related to the antioxidant properties of the components of the studied extracts. The main components identified in V. opulus fruit juice are phenolic compounds, which are involved in direct free radical quenching. Our previous studies revealed that the comparable dosages of $V$. opulus extracts were also able to decrease radicals generation and intracellular ROS level in Caco-2 and MIN6 cells [18,21]. Furthermore, V. opulus compounds were able to enhance activity of enzymes involved in cellular defense system, i.e., glutathione peroxidase (GPx). Nevertheless, the elevated dosage of PJ $(50 \mu \mathrm{g} / \mathrm{mL})$ increased intracellular oxidative stress as a result of the mitochondrial depolarization induced by sample components [21]. The observed reduction in ROS level for PJ at $100 \mu \mathrm{g} / \mathrm{mL}$ concentration confirms its cytotoxic ability (demonstrated previously in Figure 3), leading to a decrease in cell number and the induction of cellular death.

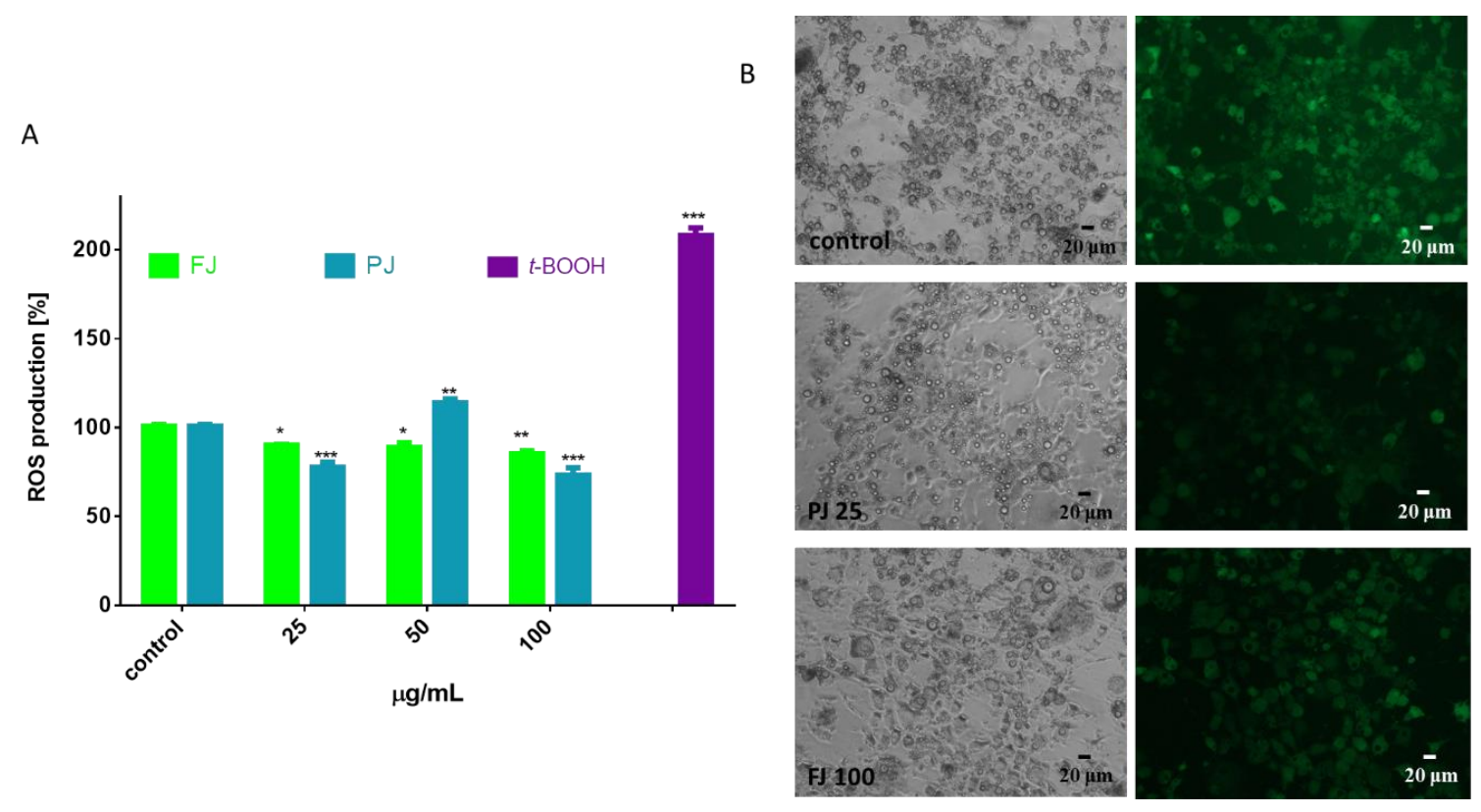

Figure 10. Influence of $V$. opulus FJ and PJ preparations on the intracellular reactive oxygen species generation analyzed by DCFH-DA assay in differentiated 3T3-L1 cells (A); control cells were not exposed to any compound; as a positive control for ROS generation, $500 \mu \mathrm{M}$ t-BOOH was used; values are means \pm standard deviations from at least three independent experiments, $n \geq 9$; statistical significance was calculated versus control cells ${ }^{*} p \leq 0.05,{ }^{* *} p \leq 0.01,{ }^{* * *} p \leq 0.001$. Cells visualized under phase-contrast and fluorescent microscope (200× magnification) (B).

Differentiated adipocytes are able to secrete proteins that are responsible for adipose tissue remodeling, as well as inflammation generation. The most abundant adipokine is adiponectin, the levels of which are decreased in subjects with diet-related diseases, such as obesity or type 2 diabetes. Activated PPAR $\gamma, \mathrm{C} / \mathrm{EBP} \alpha$ and SREBP1c stimulate its expression in adipocyte [7]. Adiponectin targets adiponectin receptor (AdipoR) mainly regulates energy metabolism and reveals protective insulin-sensitizing and anti-inflammatory properties. The second protein, leptin, plays role in appetite suppression and the downregulation of food intake; however, its serum concentration is increased in obesity due to observed leptin resistance [46]. As it is demonstrated in Figure 11, the incubation of differentiated 3T3-L1 cells with PJ preparation increased the expression of adiponectin gene by 15\%, as well as up-regulated its extracellular secretion by $25 \%$ compared to the control cells. In the same way, there was a noticeably diminished level of lipid and TAG accumulation in 3T3-L1 cells. Despite the lack of the FJ and PJ influence on leptin mRNA expression level, there was an observed relevant decrease in leptin secretion by cells treated with these preparations (15-20\%). Studies performed in vivo demonstrated that chlorogenic acid (dominant phenolic compound in FJ and PJ) effectively 
reduced blood and liver lipid accumulation, as well as decreased amounts of leptin and insulin in plasma [47]. The enlargement of adipocytes induces the release of free fatty acids, which generate oxidative stress, leading to cellular structures damage, but also stimulate the secretion of inflammatory cytokines. Among cytokines, the most related to obesity and insulin resistance are tumor necrosis factor $\alpha(\mathrm{TNF} \alpha)$ and interleukin-6 (Il-6). Chlorogenic acid has an anti-inflammatory effect, reducing the cellular release of TNF $\alpha$, Il-1 $\beta$ and Il- 6 cytokine [9,48-50]. Figure 11 shows that only purified juice declined the expression of TNF $\alpha$ mRNA by $20 \%$. TNF $\alpha$ protein level was also downregulated by $\mathrm{PJ}$ to $70 \%$. It is known that $\mathrm{TNF} \alpha$ regulates the synthesis of pro-inflammatory cytokines, including Il-6 [51]. In concordance, both $V$. opulus preparations decreased the secretion of Il-6 protein to $40-70 \%$. In contrast, Il-6 mRNA level was not changed. Hence, we can conclude that the FJ and PJ components could be further checked with animal models of obesity or insulin resistance as potential preventive agents against chronic inflammatory response.

A

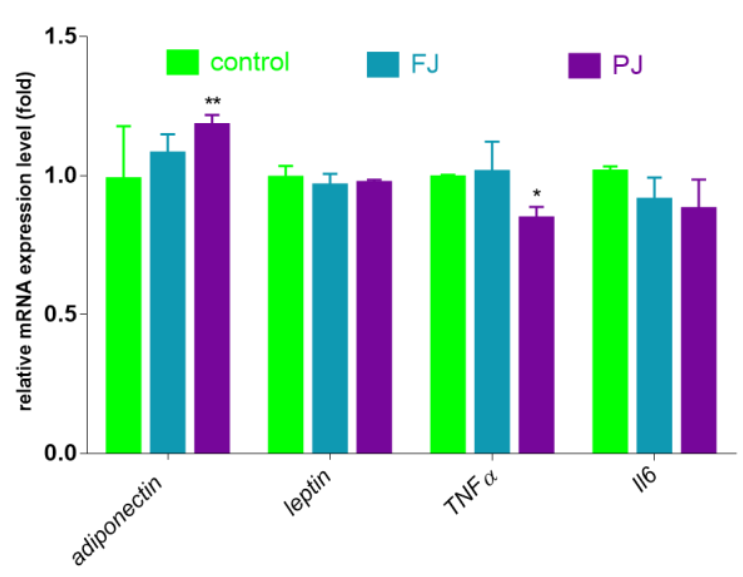

B

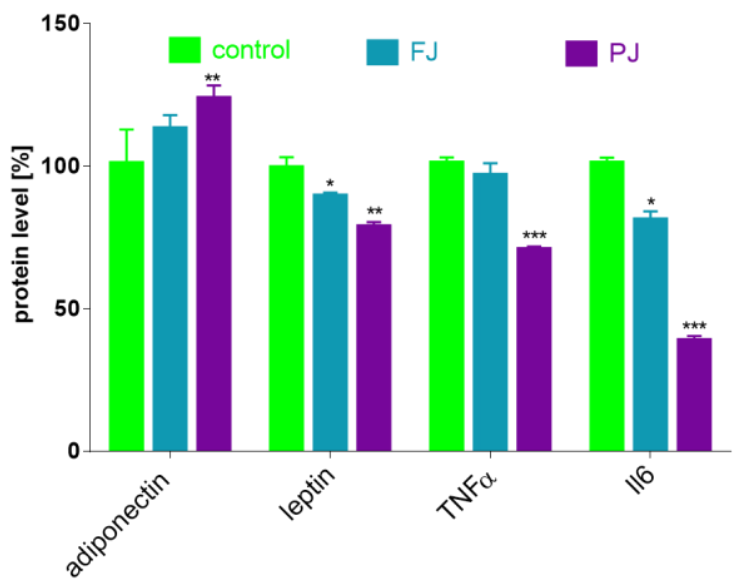

Figure 11. Influence of $V$. opulus FJ and PJ preparations on the mRNA expression (A) and protein secretion (B) of selected adipokines and cytokines in differentiated 3T3-L1 cells; control cells were not exposed to any compound; values are means \pm standard deviations, $n=6$; statistical significance was calculated versus control cells ${ }^{*} p \leq 0.05,{ }^{* *} p \leq 0.01,{ }^{* * *} p \leq 0.001$.

To the best of our knowledge, there are no reports on $V$. opulus fruit influence on lipid metabolism regulation with PPAR $\gamma$ involvement. However, it is known that chlorogenic acid, the main phenolic constituent of V. opulus, was able to suppress mRNA level of Ppar $\gamma, \mathrm{Cd} 36$ and Fabp4 in liver and white adipose tissue in mice treated with a high-fat diet [49]. The results obtained by Villalpando-Arteaga et al. are comparable and show that aqueous extract from Hibiscus sabdariffa containing chlorogenic acid, delphinidin-3-sambubioside and cyanidin-3-sambubioside, attenuated steatosis progression and Ppary expression in the liver of obese mice [52]. Chlorogenic acid and rutin (quercetin-3-rutinoside) were observed as effective inhibitors of the accumulation of intracellular triglyceride content in 3T3-L1 cells [53]. They were able to down-regulate the expression of adipogenic transcription factors (PPAR $\gamma$ and C/EBP) and adipocyte-specific proteins (leptin), as well as up-regulate adiponectin. In comparison, other study performed with 3T3-L1 differentiated cells identified chlorogenic acid as an agonist of PPAR $\gamma 2$, which promoted adipocyte differentiation via the elevation of PPAR $\gamma 2$, CEBP and SREBP-1 mRNA and protein level [54]. Nevertheless, the other phenolic compounds identified in V. opulus fruit were proved to decrease the adipogenesis process [55-57]. Cyanidin-3-glucoside was able to elevate adiponectin gene expression in human adipocytes, whereas, in C57B1/6J mice diminished the expression of Fas and Srebp-1 and decreased body weight and hepatic lipid content [55,57]. Reduced levels of SREBP-1c, ACC and FAS were noted in 3T3-L1 cells after treatment with quercetin derivatives and rutin [58,59]. Additionally, rutin and catechin were capable of suppressing adipocyte differentiation via PPAR $\gamma$ and $R \times R \alpha$ receptor down-regulation [59-61]. Catechin effectively suppressed 
3T3-L1 cells differentiation with the inhibition of the expression and protein levels of PPAR $\gamma$ and FAS; however, the observed results were stronger after the cells' treatment with a combination of catechin and caffeine [62]. Procyanidin B2 and other derivatives present in FJ and PJ preparations were also confirmed as regulators of adipocyte triglyceride content with PPAR $\gamma$ involvement $[63,64]$.

\subsection{The Effects of V. opulus on Activity of PPAR $\gamma$}

Among different transcriptional activators of adipogenesis, PPAR $\gamma$, which belongs to nuclear receptors family, is considered as a master regulator of adipocytes differentiation. It interplays with other transcription factors and binds numerous proteins involved in the regulation of transcription, such as PPAR $\gamma$ cofactor $1 \alpha$ (PGC- $1 \alpha)[8,65]$. PPAR $\gamma$ activity can be regulated by ligand binding to the ligand-binding domain, inducing protein conformational changes. Among natural precursors of ligands for PPAR $\gamma$ are long-chained fatty acids, as well as nitriled or oxidized lipids [66]. Thus, to detect if $V$. opulus phenolic components directly affect the activity of PPAR $\gamma$ protein, we used the cell-based reporter gene assay. As a PPAR $\gamma$ activator, we used rosiglitazone at $1 \mu \mathrm{M}$ concentration, while compound T0070967 $(1 \mu \mathrm{M})$ was used as an antagonist. As it is shown in Figure 12, after the cells' incubation with agonist PPAR $\gamma$, activity was elevated almost twofold compared to the control cells, whereas the antagonist decreased the receptor activity by $40 \%$. PPAR $\gamma$ activity was diminished by $25 \%$ after treatment with PJ, whereas FJ had no effect. In addition, the cells' preliminary incubation with tested preparations significantly decreased receptor activity after rosiglitazone treatment by $90 \%$ and $40 \%$ for PJ and FJ, respectively. Based on this, we can suspect that $V$. opulus juice components possess antagonist potential against PPAR $\gamma$ receptor.

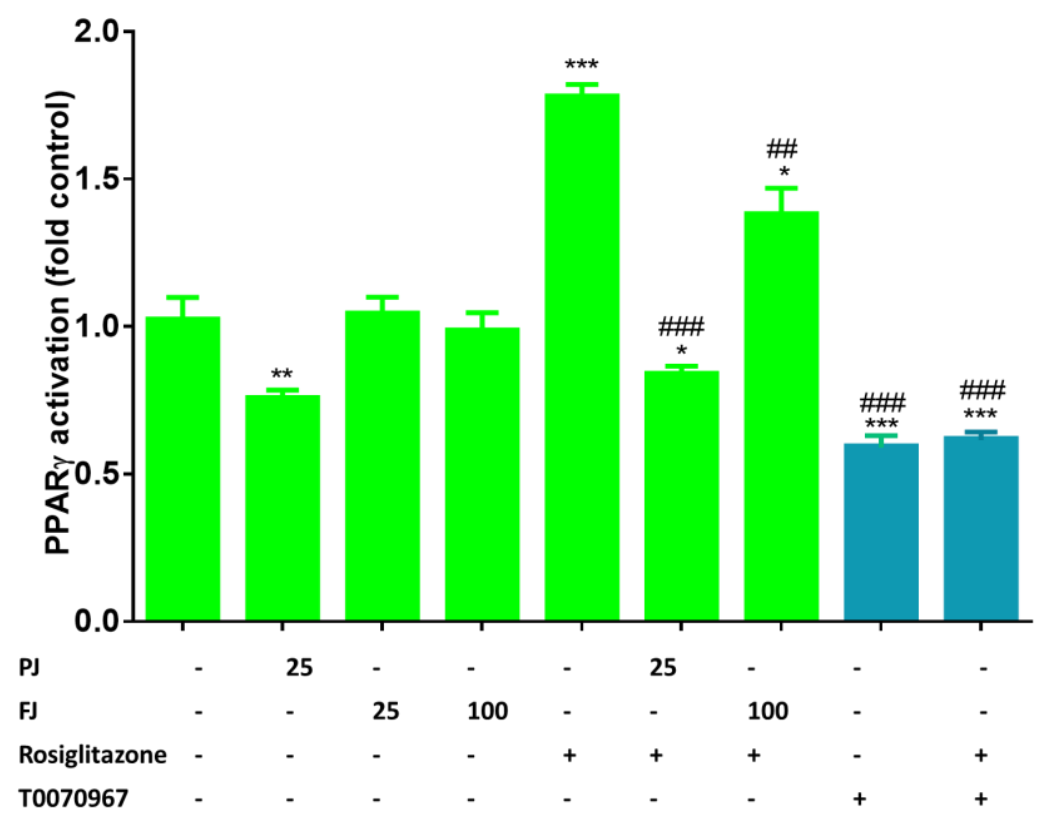

Figure 12. The effect of V. opulus FJ ( 25 and $100 \mu \mathrm{g} / \mathrm{mL})$ and PJ $(25 \mu \mathrm{g} / \mathrm{mL})$ preparations on PPAR $\gamma$ activation in GeneBLAzer®PPAR gamma 293H DA reporter gene assay; as agonist $1 \mu \mathrm{M}$ rosiglitazone was used, whereas as antagonist $1 \mu \mathrm{M}$ T0070967; the control cells were not exposed to any compound; the values are means \pm standard deviations, $n=4$; the statistical significance was calculated versus control cells with ${ }^{*} p \leq 0.05,{ }^{* *} p \leq 0.01,{ }^{* * *} p \leq 0.001$; the statistical significance was calculated versus cells after rosiglitazone treatment with ${ }^{\# \#} p \leq 0.01,{ }^{\# \#} p \leq 0.001$.

$\operatorname{PPAR} \gamma$ protein belongs to the superfamily of nuclear receptors and possesses six domains, among which the ligand-binding domain (LBD), via interactions with ligands, is involved in the modulation of PPAR $\gamma$ activity. Afterwards, the ligand binding induces a change in the receptor conformation dynamic process of corepressor dissociation, and coactivator recruitment is started [14]. To explore 
the potential interaction between $V$. opulus juice components and PPAR $\gamma$ protein, molecular docking simulation was performed with the binding pocket located behind the H3 helix of PPAR $\gamma$ receptor. There are many PPAR $\gamma$ receptor agonists that locate in this binding pocket, i.e. indol-1-yl acetic acid, nonaoic acid or amorfrutin 1 [67-69]. As an example of the PPAR $\gamma$ agonist in the analyzed model, we used rosiglitazone (Figure 13), which locates deeply inside the receptor-binding pocket. The simple validation of the docking method showed slight differences between rosiglitazone in crystal structure and docked molecule in the pocket; however, this effect was acceptable for performed research with the main phenolic compounds identified in $V$. opulus juice. Molecular modeling with Autodock Vina located chlorogenic acid and (+)- catechin inside the binding pocket. Among the studied compounds, chlorogenic acid, (+)- catechin and rosiglitazone showed similar binding affinities (Figure 13). Additionally, the chlorogenic acid molecule orientation in pocket also revealed some similarity to that of rosiglitazone. Despite this, neither chlorogenic acid nor (+)- catechin did not create any possible hydrogen bond to serine 289 or tyrosine 473 of PPAR $\gamma$, which were essentially made by the rosiglitazone molecule. This gives some hint to predict that these compounds have some potential to activate PPAR $\gamma$, but their mechanism of action could be different than rosiglitazone; they could bind to a different part of the receptor and change its conformation in a similar way to the partial agonist. In contrast to these two phenolic ligands, procyanidins B1 and C1 cannot fit into the binding pocket because of their more complex structures and larger shape. In this case, estimated high binding affinity resulted from numerous hydrogen bonds created between procyanidins and the residues present in surface of receptor. Thus, procyanidins present in $V$. opulus juice could clog the entrance to the PPAR $\gamma$ binding pocket and block it from a potential agonist entering, which could resemble inverse agonist behavior. As a result, the reduction of PPAR $\gamma$ activity may occur despite the presence of chlorogenic acid, which was demonstrated to be a PPAR $\gamma$ agonist. Among the limitations of performed basic molecular docking, there is a lack of prediction of the most favorable energetic conformation for research space, as well as kinetic data describing designed configuration. Thus, further studies with kinetic modeling or isothermal titration calorimetry would give more detailed information in this regard. Still, the results obtained with molecular docking are in agreement with the biological experiments showing a reduction of signal transduction controlled by PPAR $\gamma$, and, finally, a decrease in 3T3-L1 cells adipogenesis. Therefore, PPAR $\gamma$ transcriptional potential could be modulated on different levels: by the regulation of mRNA and protein levels, as well as conformational changes made after its binding with ligands leading to protein subcellular distribution, heterodimers' formation, and, finally, binding with peroxisome proliferator hormone response elements present in promoters of PPAR-responsive genes. The studies performed recently identified chlorogenic acid as an agonist of the PPAR $\gamma 2$ receptor responsible for the enhanced differentiation of 3T3-L1 cells [54]. In the identified molecular mechanism downregulation of adipocyte differentiation-inhibitor gene, Pref1 was observed, which was accompanied by the upregulation of CEBP and SREBP-1 transcriptional factors. Microscopic observations demonstrated the elevation of PPAR $\gamma$ in the nucleus fraction, as well as in total cell lysate. Based on this data and our results, we can conclude that other V. opulus juice components, such as proanthocyanins, may be responsible for the observed PPAR $\gamma$ limitation.

To PPAR $\gamma$ endoligands belong unsaturated fatty acids or eicosanoids, whereas, among synthetic ligands, the most known are thiazolidinediones, such as rosiglitazone [5]. A recent study presented chemically pure phenolic compounds' abilities to regulate the adipogenesis process and matched the obtained results with the molecular docking analysis of their binding affinity to PPAR $\gamma$ LBD [70]. As it was shown, the obtained in silico binding affinities of quercetin, apigenin, resveratrol, ellagic acid and coumaric acid to PPAR $\gamma$ were in agreement with these compounds' inhibition potential of 3T3-L1 cells differentiation. However, it can still be supposed that the nuclear receptor ligand activity might be limited not only by its bioavailability, but also by its intracellular uptake. 


\begin{tabular}{|c|c|c|c|c|}
\hline Ligand & Pocket visualization & $\begin{array}{l}\text { Rosiglitazone from crystal vs } \\
\text { ligand from molecular docking }\end{array}$ & Ligand interaction & $\begin{array}{l}\text { Binding } \\
\text { affinity } \\
{[\mathrm{kJ} / \mathrm{mol}]}\end{array}$ \\
\hline rosiglitazone & & & & $-33,91$ \\
\hline$(+)$ - catechin & & & & $-29,31$ \\
\hline $\begin{array}{l}\text { chlorogenic } \\
\text { acid }\end{array}$ & & & & $-33,08$ \\
\hline procyanidin B1 & & & & $-40,61$ \\
\hline procyanidin C1 & Ear $45 z$ & & & $-39,36$ \\
\hline & & $60=$ & & \\
\hline
\end{tabular}

Figure 13. Interaction of tested phenolic compounds with PPAR $\gamma$ receptor verified with molecular docking. The active site of the PPAR $\gamma$ receptor is located behind the E3 helix, where a small cavity is formed. An agonist of PPARy, rosiglitazone, enters the receptor-active site and locates deep inside the binding pocket. Molecular models of rosiglitazone, (+)- catechin, chlorogenic acid, procyanidin B1 and procyanidin $\mathrm{C} 1$ are shown on the entrance of the active pocket site. Orientation of models are presented in comparison to the crystal model of rosiglitazone. Interactions of the models with corresponding binding affinities are presented in the two last columns. Molecular docking was performed with AutoDock Vina.

\section{Conclusions}

The present work provides direct evidence of the V. opulus juice effect on the adipogenesis of 3T3-L1 cells (Figure 14). Phenolic compounds identified in juice, mainly chlorogenic acid, procyanidins and catechins, were found to suppress adipogenesis by the downregulation of major regulators of adipogenesis, such as PPAR $\gamma, \mathrm{C} / \mathrm{EBP} \alpha$ and SREBP-1c. The regulation of PPAR $\gamma$-mediated $\beta$-lactamase expression in reporter gene assay, as well molecular docking, suggested that $V$. opulus components may work as a PPAR $\gamma$ antagonist. As result, the levels of enzymes involved in lipid metabolism, such as FAS or ACC, were decreased, along with adipokine TNF $\alpha$, Il-6 and leptin. Additionally, V. opulus juice was able to inhibit pancreatic lipase, which potentially could reduce the uptake of fatty acids in the digestive tract and the storage of body fat in the adipose tissue. 


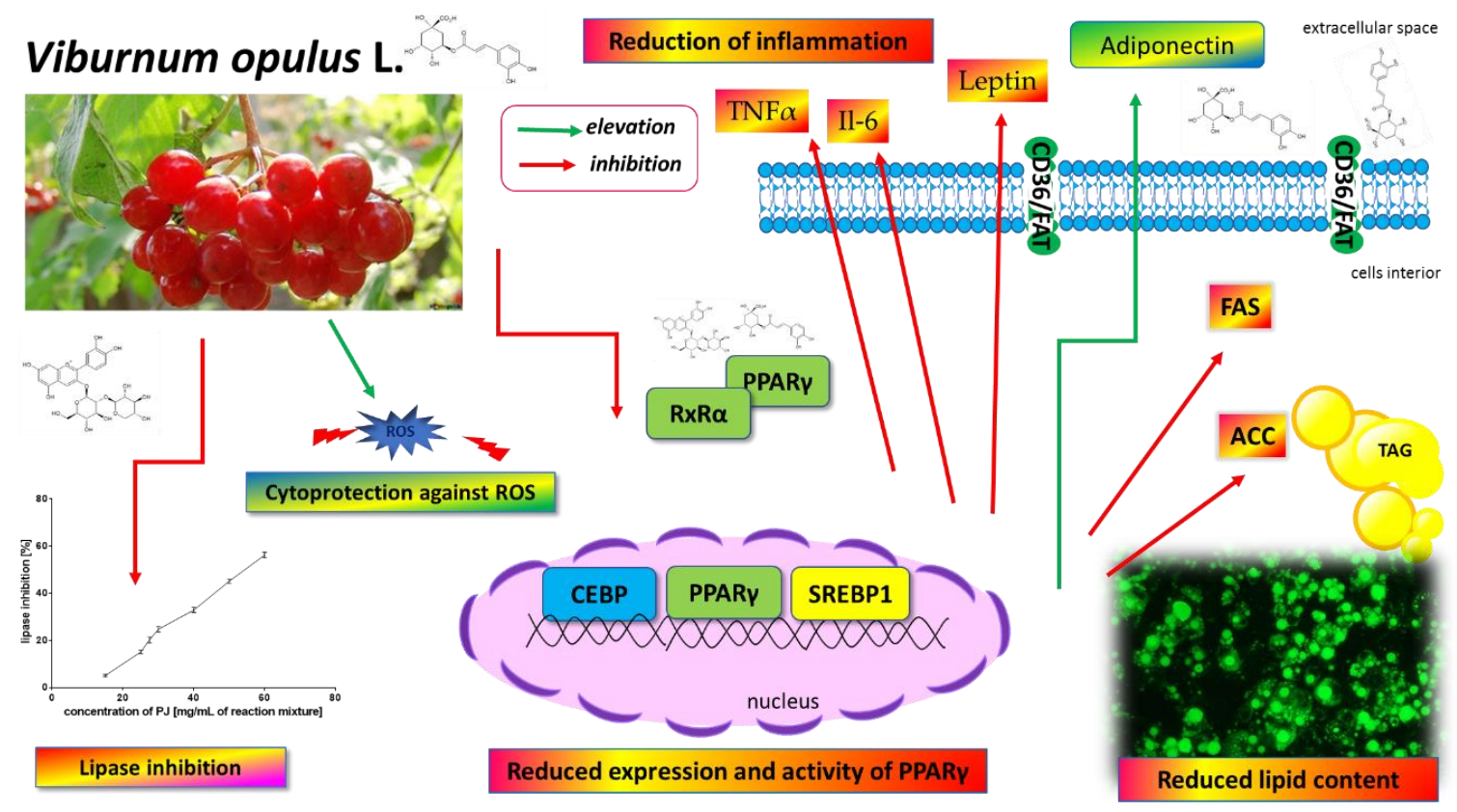

Figure 14. V. opulus juice phenolic compounds as modulators of lipids metabolism-the proposed mechanism of action. $V$. opulus downregulates the adipogenesis of 3T3-L1 cells, decreases the expression and activity of the PPAR $\gamma$ nuclear receptor as well as PPAR $\gamma$-regulated proteins (i.e., fatty acid synthase (FAS), acetyl-CoA carboxylase (ACC)), diminishes the release of inflammatory cytokines and leptin, possesses cytoprotective activity against ROS generation and increases adiponectin secretion. V. opulus inhibits pancreatic-lipase and limits fatty acid release from the food matrix.

Our results contribute to elucidate $V$. opulus phenolic compounds' molecular mechanism in adipogenesis regulation. However, observed adipogenesis inhibitory outcome needs further molecular evaluation after $V$. opulus juice in vitro digestion and its incubation with gut microflora. These processes may greatly influence the composition of the studied phytocompounds, as well as the activity. Taking into account possible $V$. opulus cellular type-dependent in vitro activity, its potential usage as a diet component needs further in vivo studies performed with an animal obesity model to show its efficacy in the regulation of lipid metabolism at safety doses.

Author Contributions: M.Z.-S. conceptualization, supervision, methodology, lab work with cell cultures and results, writing_original draft preparation, review, and editing; N.P. lab work and results, obtaining and characterization of $V$. opulus phenolics; M.S. molecular modeling; A.P. involved in study conceptualization, lipase inhibition studies, V. opulus phenolics characterization; funding acquisition. All authors have read and agreed to the published version of the manuscript.

Funding: The research was supported by grant number 2016/23/B/NZ9/03629 from The National Science Centre, Poland.

Acknowledgments: Małgorzata Zakłos-Szyda gratefully acknowledges Maria Koziołkiewicz for her encouragement for opening new research possibilities and critical comments.

Conflicts of Interest: The authors declare no conflict of interest.

\section{References}

1. Cataloguing, W.L. Global Report on Diabetes; WHO Press: Geneva, Switzerland, 2016; pp. 6-86.

2. Pascual-Serrano, A.; Arola-Arnal, A.; Suárez-García, S.; Bravo, F.I.; Suárez, M.; Arola, L.; Bladé, C. Grape seed proanthocyanidin supplementation reduces adipocyte size and increases adipocyte number in obese rats. Int. J. Obes. 2017, 41, 1246-1255. [CrossRef] [PubMed]

3. Ruiz-Ojeda, F.J.; Rupérez, A.I.; Gomez-Llorente, C.; Gil, A.; Aguilera, C.M. Cell models and their application for studying adipogenic differentiation in relation to obesity: A review. Int. J. Mol. Sci. 2016, 17, 1040. [CrossRef] [PubMed] 
4. Graham, M.R.; Baker, J.S.; Davies, B. Causes and consequences of obesity: Epigenetics or hypokinesis? Diabetes Metab. Syndr. Obes. Targets Ther. 2015, 8, 455-460.

5. Ma, X.; Wang, D.; Zhao, W.; Xu, L. Deciphering the roles of PPAR $\gamma$ in adipocytes via dynamic change of transcription complex. Front. Endocrinol. 2018, 9, 473. [CrossRef]

6. Plutzky, J. The PPAR-RXR transcriptional complex in the vasculature: Energy in the balance. Circ. Res. 2011, 108, 1002-1016. [CrossRef]

7. Zheng, F.; Zhang, S.; Lu, W.; Wu, F.; Yin, X.; Yu, D.; Pan, Q.; Li, H. Regulation of insulin resistance and adiponectin signaling in adipose tissue by liver $\mathrm{X}$ receptor activation highlights a cross-talk with PPAR $\gamma$. PLOS ONE 2014, 9, e101269. [CrossRef]

8. Medina-Gomez, G.; Gray, S.; Vidal-Puig, A. Adipogenesis and lipotoxicity: Role of peroxisome proliferator-activated receptor $\gamma(\mathrm{PPAR} \gamma)$ and PPAR $\gamma$ coactivator-1 (PGC1). Public Health Nutr. 2007, 10, 1132-1137. [CrossRef]

9. Kern, L.; Mittenbühler, M.J.; Vesting, A.J.; Ostermann, A.L.; Wunderlich, C.M.; Wunderlich, F.T. Obesity-induced TNF $\alpha$ and IL- 6 signaling: The missing link between obesity and inflammation- driven liver and colorectal cancers. Cancers 2019, 11, 24. [CrossRef]

10. Austin, D.; Hamilton, N.; Elshimali, Y.; Pietras, R.; Wu, Y. Estrogen receptor-beta is a potential target for triple negative breast cancer treatment. Oncotarget 2018, 9, 33912-33930. [CrossRef]

11. Rigano, D.; Sirignano, C.; Taglialatela-Scafati, O. The potential of natural products for targeting PPAR $\alpha$. Acta Pharm. Sin. B 2017, 7, 427-438. [CrossRef]

12. Martens, F.M.A.C.; Visseren, F.L.J.; Lemay, J.; de Koning, E.J.P.; Rabelink, T.J. Metabolic and additional vascular effects of thiazolidinediones. Drugs 2002, 62, 1463-1480. [CrossRef] [PubMed]

13. Siriwardhana, N.; Kalupahana, N.S.; Cekanova, M.; LeMieux, M.; Greer, B.; Moustaid-Moussa, N. Modulation of adipose tissue inflammation by bioactive food compounds. J. Nutr. Biochem. 2013, 24, 613-623. [CrossRef]

14. Filho, H.V.R.; Videira, N.B.; Bridi, A.V.; Tittanegro, T.H.; Batista, F.A.H.; de Pereira, J.G.; de Oliveira, P.S.L.; Bajgelman, M.C.; Le Maire, A.; Figueira, A.C.M. Screening for PPAR non-agonist ligands followed by characterization of a hit, AM-879, with additional no-adipogenic and cdk5-mediated phosphorylation inhibition properties. Front. Endocrinol. 2018, 9, 11. [CrossRef]

15. Perova, I.B.; Zhogova, A.A.; Cherkashin, A.V.; Éller, K.I.; Ramenskaya, G.V. Biologically active substances from european guelder berry fruits. Pharm. Chem. J. 2014, 48, 332-339. [CrossRef]

16. Zakłos-Szyda, M.; Pawlik, N. The influence of Viburnum opulus polyphenolic compounds on metabolic activity and migration of HeLa and MCF cells. Acta Innov. 2019, 33, 33-42. [CrossRef]

17. Česoniene, L.; Daubaras, R.; Vencloviene, J.; Viškelis, P. Biochemical and agro-biological diversity of Viburnum opulus genotypes. Cent. Eur. J. Biol. 2010, 5, 864-871. [CrossRef]

18. Zakłos-Szyda, M.; Pawlik, N.; Polka, D.; Nowak, A.; Koziołkiewicz, M.; Podsędek, A. Viburnum opulus fruit phenolic compounds as cytoprotective agents able to decrease free fatty acids and glucose uptake by Caco-2 cells. Antioxidants 2019, 8, 262. [CrossRef] [PubMed]

19. Stępień, A.; Aebisher, D.; Bartusik-Aebischer, D. Anticancer properties of Viburnum. Eur. J. Clin. Exp. Med. 2018, 1361, 47-52. [CrossRef]

20. Zakłos-Szyda, M.; Majewska, I.; Redzynia, M.; Koziołkiewicz, M. Antidiabetic effect of polyphenolic extracts from selected edible plants as $\alpha$-amylase, $\alpha$-glucosidase and PTP1B inhibitors, and $\beta$ pancreatic cells cytoprotective agents-A comparative study. Curr. Top. Med. Chem. 2015, 15, 2431-2444. [CrossRef]

21. Zakłos-Szyda, M.; Kowalska-Baron, A.; Pietrzyk, N.; Drzazga, A.; Podsędek, A. Evaluation of Viburnum opulus L. fruit phenolics cytoprotective potential on insulinoma MIN6 Cells relevant for diabetes mellitus and obesity. Antioxidants 2020, 9, 433. [CrossRef]

22. Zebisch, K.; Voigt, V.; Wabitsch, M.; Brandsch, M. Protocol for effective differentiation of 3T3-L1 cells to adipocytes. Anal. Biochem. 2012, 425, 88-90. [CrossRef] [PubMed]

23. Sosnowska, D.; Podsędek, A.; Redzynia, M.; Kucharska, A.Z. Inhibitory effect of black chokeberry fruit polyphenols on pancreatic lipase-Searching for most active inhibitors. J. Funct. Foods 2018, 49, 196-204. [CrossRef]

24. Jang, J.Y.; Bae, H.; Lee, Y.J.; Choi, Y., II; Young, I.L.; Kim, H.J.; Park, S.B.; Suh, S.W.; Kim, S.W.; Han, B.W. Structural Basis for the Enhanced Anti-Diabetic Efficacy of Lobeglitazone on PPAR $\gamma$. Sci. Rep. 2018, 8, 31. [CrossRef] [PubMed] 
25. Kraujalyte, V.; Rimantas, P.; Pukalskas, A.; Laima, C. Antioxidant properties and polyphenolic compositions of fruits from different European cranberrybush (Viburnum opulus L.) genotypes. Food Chem. 2013, 141, 3695-3702. [CrossRef]

26. Karaçelik, A.A.; Kucuk, M.; Iskafyeli, Z.; Aydemir, S.; De Smet, S.; Miserez, B.; Sandra, P. Antioxidant components of Viburnum opulus L. determined by on-line HPLC-UV-ABTS radical scavenging and LC-UV-ESI-MS methods. Food Chem. 2015, 175, 106-114. [CrossRef]

27. Velioglu, Y.S.; Ekici, L.; Poyrazoglu, E.S. Phenolic composition of European cranberrybush (Viburnum opulus L.) berries and astringency removal of its commercial juice. Int. J. Food Sci. Technol. 2006, 9205, 1011-1015. [CrossRef]

28. McDougall, G.J.; Kulkarni, N.N.; Stewart, D. Berry polyphenols inhibit pancreatic lipase activity in vitro. Food Chem. 2009, 115, 193-199. [CrossRef]

29. Gironés-Vilaplana, A.; Villaño, D.; Moreno, D.A.; García-Viguera, C. New isotonic drinks with antioxidant and biological capacities from berries (maqui, açaí and blackthorn) and lemon juice. Int. J. Food Sci. Nutr. 2013, 64, 897-906. [CrossRef]

30. Fabroni, S.; Ballistreri, G.; Amenta, M.; Romeo, F.V.; Rapisarda, P. Screening of the anthocyanin profile and in vitro pancreatic lipase inhibition by anthocyanin-containing extracts of fruits, vegetables, legumes and cereals. J. Sci. Food Agric. 2016, 96, 4713-4723. [CrossRef]

31. Zheng, G.; Qiu, Y.; Zhang, Q.F.; Li, D. Chlorogenic acid and caffeine in combination inhibit fat accumulation by regulating hepatic lipid metabolism-related enzymes in mice. Br. J. Nutr. 2014, 112, 1034-1040. [CrossRef]

32. Worsztynowicz, P.; Napierała, M.; Białas, W.; Grajek, W.; Olkowicz, M. Pancreatic $\alpha$-amylase and lipase inhibitory activity of polyphenolic compounds present in the extract of black chokeberry (Aronia melanocarpa L.). Process Biochem. 2014, 49, 1457-1463. [CrossRef]

33. Sugiyama, H.; Akazome, Y.; Shoji, T.; Yamaguchi, A.; Yasue, M.; Kanda, T.; Ohtake, Y. Oligomeric procyanidins in apple polyphenol are main active components for inhibition of pancreatic lipase and triglyceride absorption. J. Agric. Food Chem. 2007, 55, 4604-4609. [CrossRef] [PubMed]

34. Kowalska, K.; Olejnik, A.; Rychlik, J.; Grajek, W. Cranberries (Oxycoccus quadripetalus) inhibit adipogenesis and lipogenesis in 3T3-L1 cells. Food Chem. 2014, 148, 246-252. [CrossRef] [PubMed]

35. Lefterova, M.I.; Haakonsson, A.K.; Lazar, M.A.; Mandrup, S. PPAR $\gamma$ and the global map of adipogenesis and beyond. Trends Endocrinol. Metab. 2014, 25, 293-302. [CrossRef]

36. Česonienè, L.; Daubaras, R.; Viškelis, P. Evaluation of productivity and biochemical components in fruit of different Viburnum accessions. Biologija 2008, 54, 93-96. [CrossRef]

37. Hiebl, V.; Ladurner, A.; Latkolik, S.; Dirsch, V.M. Natural products as modulators of the nuclear receptors and metabolic sensors LXR, FXR and RXR. Biotechnol. Adv. 2018, 36, 1657-1698. [CrossRef]

38. Maire, A.; Teyssier, C.; Balaguer, P.; Bourguet, W.; Germain, P. RAR-Specific Ligands and Their Combinations. Cells 2019, 8, 1392. [CrossRef]

39. Zhang, J.; Tang, H.; Deng, R.; Wang, N.; Zhang, Y.; Wang, Y.; Liu, Y.; Li, F.; Wang, X.; Zhou, L. Berberine suppresses adipocyte differentiation via decreasing CREB transcriptional activity. PLoS ONE 2015, 10, e0125667. [CrossRef]

40. Hallenborg, P.; Petersen, R.K.; Kouskoumvekaki, I.; Newman, J.W.; Madsen, L.; Kristiansen, K. The elusive endogenous adipogenic PPAR $\gamma$ agonists: Lining up the suspects. Prog. Lipid Res. 2016, 61, 149-162. [CrossRef]

41. Schneider, H.; Staudacher, S.; Poppelreuther, M.; Stremmel, W.; Ehehalt, R.; Füllekrug, J. Protein mediated fatty acid uptake: Synergy between CD36 / FAT-facilitated transport and acyl-CoA synthetase-driven metabolism. Arch. Biochem. Biophys. 2014, 546, 8-18. [CrossRef]

42. Crewe, C.; Zhu, Y.; Paschoal, V.A.; Joffin, N.; Ghaben, A.L.; Gordillo, R.; Oh, D.Y.; Liang, G.; Horton, J.D.; Scherer, P.E. SREBP-regulated adipocyte lipogenesis is dependent on substrate availability and redox modulation of mTORC1. JCI Insight 2019, 4. [CrossRef] [PubMed]

43. Gao, Y.; Zhou, Y.; Xu, A.; Wu, D. Effects of an AMP-activated protein kinase inhibitor, compound C, on adipogenic differentiation of 3T3-L1 cells. Biol. Pharm. Bull. 2008, 31, 1716-1722. [CrossRef] [PubMed]

44. Zakłos-Szyda, M.; Pawlik, N. Japanese quince (Chaenomeles japonica L.) fruit polyphenolic extract modulates carbohydrate metabolism in HepG2 cells via AMP-activated protein kinase. Acta Biochim. Pol. 2018, 65, 67-78. [CrossRef] [PubMed] 
45. Li, Y.; Xu, S.; Mihaylova, M.; Zheng, B.; Hou, X.; Jiang, B.; Luo, Z.; Lefai, E.; Shyy, J.Y.; Gao, B.; et al. AMPK Phosphorylates and Inhibits SREBP Activity to Attenuate Hepatic Steatosis and Atherosclerosis in Diet-induced Insulin Resistant Mice. Cell Metab. 2011, 13, 376-388. [CrossRef] [PubMed]

46. Zhang, Y.; Dallner, O.S.; Nakadai, T.; Fayzikhodjaeva, G.; Lu, Y.H.; Lazar, M.A.; Roeder, R.G.; Friedman, J.M. A noncanonical PPAR $\gamma / \mathrm{RXR} \alpha$-binding sequence regulates leptin expression in response to changes in adipose tissue mass. Proc. Natl. Acad. Sci. USA 2018, 115, E6039-E6047. [CrossRef]

47. Meng, S.; Cao, J.; Feng, Q.; Peng, J.; Hu, Y. Roles of chlorogenic Acid on regulating glucose and lipids metabolism: A review. Evid. Based Complementary Altern. Med. 2013, 2013. [CrossRef]

48. Gao, R.; Yang, H.; Jing, S.; Liu, B.; Wei, M.; He, P.; Zhang, N. Protective effect of chlorogenic acid on lipopolysaccharide-induced inflammatory response in dairy mammary epithelial cells. Microb. Pathog. 2018, 124, 178-182. [CrossRef]

49. Ma, Y.; Gao, M.; Liu, D. Chlorogenic acid improves high fat diet-induced hepatic steatosis and insulin resistance in mice. Pharm. Res. 2015, 32, 1200-1209. [CrossRef]

50. Liang, N.; Kitts, D.D. Role of chlorogenic acids in controlling oxidative and inflammatory stress conditions. Nutrients 2015, 8, 16. [CrossRef]

51. Naveed, M.; Hejazi, V.; Abbas, M.; Kamboh, A.A.; Khan, G.J.; Shumzaid, M.; Ahmad, F.; Babazadeh, D.; FangFang, X.; Modarresi-Ghazani, F.; et al. Chlorogenic acid (CGA): A pharmacological review and call for further research. Biomed. Pharmacother. 2018, 97, 67-74. [CrossRef]

52. Villalpando-Arteaga, E.V.; Mendieta-Condado, E.; Esquivel-Solís, H.; Canales-Aguirre, A.A.; Gálvez-Gastélum, F.J.; Mateos-Díaz, J.C.; Rodríguez-González, J.A.; Márquez-Aguirre, A.L. Hibiscus sabdariffa L. aqueous extract attenuates hepatic steatosis through down-regulation of PPAR- $\gamma$ and SREBP-1c in diet-induced obese mice. Food Funct. 2013, 4, 618-626. [CrossRef] [PubMed]

53. Hsu, C.L.; Yen, G.C. Effects of flavonoids and phenolic acids on the inhibition of adipogenesis in 3T3-L1 adipocytes. J. Agric. Food Chem. 2007, 55, 8404-8410. [CrossRef]

54. Peng, S.G.; Pang, Y.L.; Zhu, Q.; Kang, J.H.; Liu, M.X.; Wang, Z.; Huang, Y. Chlorogenic Acid Functions as a Novel Agonist of PPAR $\gamma 2$ during the Differentiation of Mouse 3T3-L1 Preadipocytes. BioMed Res. Int. 2018, 2018. [CrossRef] [PubMed]

55. Tsuda, T.; Horio, F.; Uchida, K.; Aoki, H.; Osawa, T. Dietary Cyanidin 3-O- $\beta$-D-Glucoside-Rich Purple Corn Color Prevents Obesity and Ameliorates Hyperglycemia in Mice. J. Nutr. 2003, 133, 2125-2130. [CrossRef] [PubMed]

56. Chem, F. Regulation of Adipocyte Function by Anthocyanins. J. Agric. Food Chem. 2008, 56, 642-646.

57. Guo, H.; Xia, M.; Zou, T.; Ling, W.; Zhong, R.; Zhang, W. Cyanidin 3-glucoside attenuates obesity-associated insulin resistance and hepatic steatosis in high-fat diet-fed and db/db mice via the transcription factor FoxO1. J. Nutr. Biochem. 2012, 23, 349-360. [CrossRef] [PubMed]

58. Chyau, C.C.; Chu, C.C.; Chen, S.Y.; Duh, P. The inhibitory effects of Djulis (Chenopodium formosanum) and its bioactive compounds on adipogenesis in 3T3-L1 adipocytes. Molecules 2018, 23, 1780. [CrossRef]

59. Choi, I.; Park, Y.; Choi, H.; Lee, E.H. Anti-adipogenic activity of rutin in 3T3-L1 cells and mice fed with high-fat diet. BioFactors 2006, 26, 273-281. [CrossRef]

60. Nones, K.; Dommels, Y.E.M.; Martell, S.; Butts, C.; McNabb, W.C.; Park, Z.A.; Zhu, S.; Hedderley, D.; Barnett, M.P.G.; Roy, N.C. The effects of dietary curcumin and rutin on colonic inflammation and gene expression in multidrug resistance gene-deficient (mdr1a-/-) mice, a model of inflammatory bowel diseases. Br. J. Nutr. 2009, 101, 169-181. [CrossRef]

61. Cai, Y.; Fan, C.; Yan, J.; Tian, N.; Ma, X. Effects of rutin on the expression of PPAR $\gamma$ in skeletal muscles of $\mathrm{db} / \mathrm{db}$ mice. Planta Med. 2012, 78, 861-865. [CrossRef]

62. Zhu, X.; Yang, L.; Xu, F.; Lin, L.; Zheng, G. Combination therapy with catechins and caffeine inhibits fat accumulation in 3T3-L1 cells. Exp. Ther. Med. 2017, 13, 688-694. [CrossRef] [PubMed]

63. Pinent, M.; Bladé, M.C.; Salvadó, M.J.; Arola, L.; Hackl, H.; Quackenbush, J.; Trajanoski, Z.; Ardévol, A. Grape-seed derived procyanidins interfere with adipogenesis of 3T3-L1 cells at the onset of differentiation. Int. J. Obes. 2005, 29, 934-941. [CrossRef] [PubMed]

64. Zhang, J.; Huang, Y.; Shao, H.; Bi, Q.; Chen, J.; Ye, Z. Grape seed procyanidin B2 inhibits adipogenesis of 3T3-L1 cells by targeting peroxisome proliferator-activated receptor $\gamma$ with miR-483-5p involved mechanism. Biomed. Pharmacother. 2017, 86, 292-296. [CrossRef] [PubMed] 
65. Fujisawa, K.; Nishikawa, T.; Kukidome, D.; Imoto, K.; Yamashiro, T.; Motoshima, H.; Matsumura, T.; Araki, E. TZDs reduce mitochondrial ROS production and enhance mitochondrial biogenesis. Biochem. Biophys. Res. Commun. 2009, 379, 43-48. [CrossRef]

66. Venkataraman, B.; Ojha, S.; Belur, P.D.; Bhongade, B.; Raj, V.; Collin, P.D.; Adrian, T.E.; Subramanya, S.B. Phytochemical drug candidates for the modulation of peroxisome proliferator-activated receptor $\gamma$ in inflammatory bowel diseases. Phyther. Res. 2020, 34. [CrossRef]

67. Mahindroo, N.; Wang, C.C.; Liao, C.C.; Huang, C.F.; Lu, I.L.; Lien, T.W.; Peng, Y.H.; Huang, W.J.; Lin, Y.T.; Hsu, M.C.; et al. Indol-1-yl acetic acids as peroxisome proliferator-activated receptor agonists: Design, synthesis, structural biology, and molecular docking studies. J. Med. Chem. 2006, 49, 1212-1216. [CrossRef]

68. Liberato, M.V.; Nascimento, A.S.; Ayers, S.D.; Lin, J.Z.; Cvoro, A.; Silveira, R.L.; Martínez, L.; Souza, P.C.T.; Saidemberg, D.; Deng, T.; et al. Medium chain fatty acids are selective peroxisome proliferator activated receptor (PPAR) $\gamma$ activators and Pan-PPAR partial agonists. PLoS ONE 2012, 7, e36297. [CrossRef]

69. Weidner, C.; De Groot, J.C.; Prasad, A.; Freiwald, A.; Quedenau, C.; Kliem, M.; Witzke, A.; Kodelja, V.; Han, C.T.; Giegold, S.; et al. Amorfrutins are potent antidiabetic dietary natural products. Proc. Natl. Acad. Sci. USA 2012, 109, 7257-7262. [CrossRef]

70. Aranaz, P.; Navarro-herrera, D.; Migu, I.; Romo-hualde, A.; Miguel, L.; Mart, J.A.; Vizmanos, L.; Milagro, I.; Javier, C. Phenolic Compounds Inhibit 3T3-L1 Adipogenesis Depending on the Stage of Differentiation and Their Binding Affinity to PPAR $\gamma$. Molecules 2019, 24, 1045. [CrossRef]

(C) 2020 by the authors. Licensee MDPI, Basel, Switzerland. This article is an open access article distributed under the terms and conditions of the Creative Commons Attribution (CC BY) license (http://creativecommons.org/licenses/by/4.0/). 